\title{
Pengembangan Sektor Ekonomi Daerah Tertinggal di Provinsi Kalimantan Barat
}

\author{
Supianto* \\ Inspektorat Kabupaten Ketapang \\ Silvester Ansel Urep \\ Windhu Putra \\ Fakultas Ekonomi dan Bisnis Universitas Tanjungpura
}

\begin{abstract}
This study aims to determine the contributions and and analize the leading sectors and changes of economics structure which can be used as information of economics development in undeveloped regions in West Kalimantan. The results show that agricultures, forestries and fisheries sectors are the economics sectors with the highest average contribution rates for all underdeveloped regions in Kalimantan Barat Province; while electricity and gas procurement sectors become economics sectors with the smallest contribution average in the formation of Gross Regional Domestic Product (GRDP) of all underdeveloped regions. The real estates sector and the health services sector and social activities are the leading sectors as well as the agricultures, forestries and fisheries sectors and the mining and quarrying sectors into potential sectors to be developed into the leading sectors in disadvantaged areas. This study also shows that there has been a structural transformation of the economy from the primary sector to the tertiary and secondary sectors marked by the decline in the role of the primary sector and the increasing role of the tertiary and secondary sectors to the formation of GRDP and the absorption of manpower in all the underdeveloped regions in West Kalimantan Province.
\end{abstract}

\section{Keywords: Leading Sector and Changes of The Economics Structure}

\section{PENDAHULUAN}

Kesejahteraan masyarakat merupakan tujuan utama dan cita-cita kemerdekaan bangsa Indonesia sesuai dengan amanat Pancasila dan Undang-Undang Dasar 1945. Salah satu cara untuk mewujudkan kesejahteraan masyarakat tersebut adalah dengan memberikan kewenangan penuh kepada Pemerintah Daerah untuk mengatur dan mengurus sendiri urusan pemerintahannya termasuk dalam kegiatan perekonomiannya melalui penyelenggaraan otonomi daerah berdasarkan UU nomor 23 tahun 2014 tentang Pemerintahan Daerah. Tujuan utama penyelenggaraan otonomi daerah adalah untuk meningkatkan pelayanan publik (public sevice) dan memajukan perekonomian daerah. Otonomi daerah dan desentralisasi fiskal merupakan langkah strategis bangsa Indonesia untuk menyongsong era globalisasi ekonomi dengan memperkuat basis perokonomian daerah (Mardiasmo, 2004).

\footnotetext{
${ }^{*}$ Korespondensi: Supianto, Inspektorat Kabupaten Ketapang, Jalan A. Yani No. 110, Ketapang 78851, Kalimantan Barat, Indonesia. Email: supianto26@gmail.com
} 
Kesejateraan masyarakat Kalimantan Barat (Kalbar) dapat dilihat dari tingkat pertumbuhan ekonomi selama enam tahun terakhir mengalami pasang surut dan berada dibawah pertumbuhan ekonomi nasional, namun secara makro kinerja perekonomian Kalbar relatif baik yang ditandai dengan beberapa indikator kesejahteraan masyarakat seperti meningkatnya kualitas sumber daya manusia, menurunnya tingkat kemiskinan serta meningkatnya pendapatan perkapita. Membaiknya kondisi kinerja makro ekonomi Kalbar ini menjadi tantangan tersendiri ketika pada tahun 2015, pemerintah mengeluarkan Peraturan Presiden nomor 131 tahun 2015 yang menetapkan 8 Kabupaten dari 14 Kabupaten/Kota di Kalbar yaitu: Sambas, Bengkayang, Landak, Ketapang, Sintang, Kapuas Hulu, Melawi dan Kayong Utara sebagai daerah tertinggal di Indonesia tahun 2015-2019, dimana perekonomian masyarakat menjadi salah satu indikator dalam penetapan status daerah tertinggal.

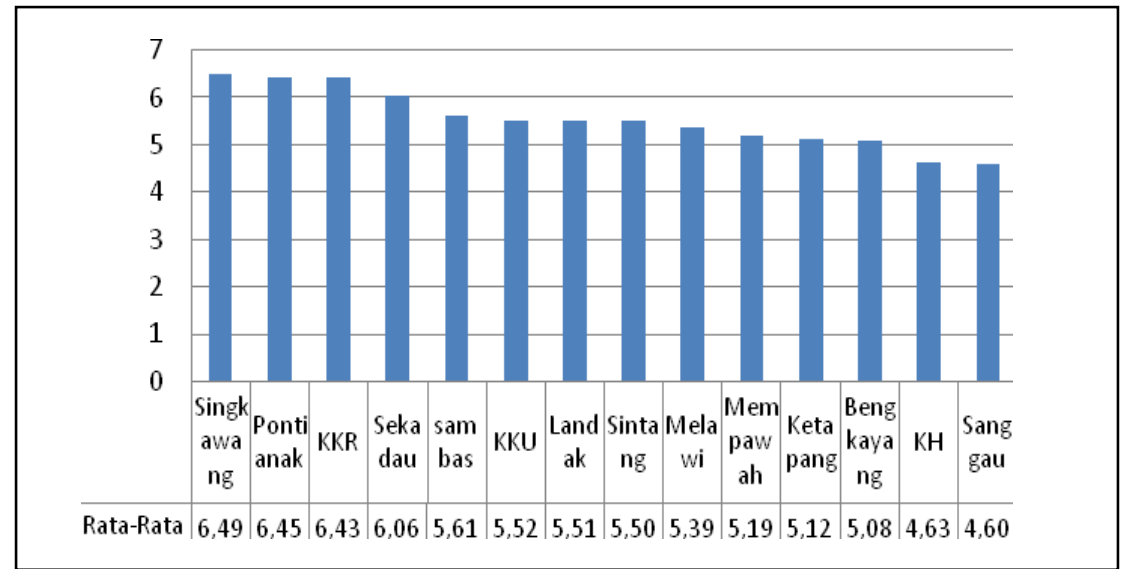

\section{Gambar 1. Rata-Rata Laju Pertumbuhan Ekonomi Kabupaten/Kota di Kalbar Tahun 2011-2015}

Sumber data: BPS Kalbar

Gambar 1 memperlihatkan bahwa selama 5 (lima) tahun terakhir rata-rata laju pertumbuhan ekonomi Kabupaten yang terkategori daerah tertinggal berada dibawah rata-rata laju pertumbuhan daerah yang maju. Kabupaten Sanggau yang terkategori bukan daerah tertinggal, rata-rata pertumbuhannya paling rendah dibandingkan daerah lain di Kalbar. Kabupaten Ketapang sebagai penyumbang Produk Domestik Regional Bruto (PDRB) terbesar ketiga pada pembentukan PDRB Kalbar selama lima tahun terakhir berada pada posisi kesebelas untuk rata-rata pertumbuhan ekonominya. Namun Kabupaten Sambas sebagai daerah tertinggal masuk dalam 5 (lima) besar rata-rata pertumbuhan ekonomi tertinggi setelah Singkawang, Pontianak, Kubu Raya, dan Sekadau. Dengan demikian jika dilihat dari aspek perekonomian daerah yang menjadi salah satu indikator penilaian daerah tertinggal, maka Kabupaten yang terkategori daerah tertinggal tersebut layak disebut daerah tertinggal dibandingkan Kabupaten/Kota lainnya di Provinsi Kalbar. 
Guna menanggulangi dan mempercepat pembangunan pada daerah tertinggal, Rencana Pembangunan Jangka Menengah Nasional (RPJMN) tahun 2015-2019 memuat 11 (sebelas) strategi pembangunan daerah tertinggal salah satunya adalah mengembangkan perekonomian masyarakat di daerah tertinggal yaitu pelaksanaan pembangunan dengan memfokuskan pada pembangunan sektor-sektor unggulan dan potensial perekonomian daerah yang memberikan dampak pengganda yang besar terhadap sektor-sektor lainnya atau perekonomian secara keseluruhan.

Oktavilia (2011) dalam penelitiannya menyimpulkan bahwa strategi pembangunan daerah tertinggal sebagai salah satu upaya untuk meminimalisir tingkat disparitas disuatu wilayah disesuikan dengan kebutuhan dan kondisi masing-masing daerah. Strategi yang dimaksud adalah dengan pengembangan ekonomi lokal, strategi ini diarahkan untuk mengembangkan ekonomi pada daerah tertinggal dengan didasarkan pada pendayagunaan sektor-sektor ekonomi potensial yang dimiliki masing-masing daerah. Demikian juga dengan penelitian yang dilakukan oleh Mardiana, Budhi \& Swara (2017) yang menyimpulkan bahwa penentuan sektor unggulan dan memahami pergeseran struktur ekonomi di daerah memiliki peran yang sangat penting dalam memaksimalkan pembangunan daerah. Oleh karena itu, strategi pembangunan daerah yang berlandaskan pertumbuhan ekonomi harus didukung oleh kebijakan yang mengarah pada pola pembangunan dengan basis daerah melalui penentuan sektor yang potensial untuk dikembangkan (Sjafrizal, 2008).

Berdasarkan hal tersebut perlu dilakukan kajian untuk mengidentifikasi sektorsektor ekonomi unggulan yang dapat dikembangkan pada daerah tertinggal dan menganalisis kontribusi serta peranan sektor ekonomi terhadap pembentukan PDRB sebagai dasar menentukan arah kebijakan pembangunan ekonomi pada daerah tertinggal dalam upaya keluar dari status daerah tertinggal di Indonesia.

\section{KAJIAN LITERATUR}

Pembangunan merupakan proses transformasi yang dalam perjalanan waktu ditandai dengan perubahan struktural yaitu perubahan pada landasan kegiatan ekonomi masyarakat. Menurut Todaro \& Smith (2011), pembangunan haruslah dipandang sebagai proses multidimensi yang melibatkan berbagai perubahan mendasar dalam struktur sosial, sikap masyarakat dan lembaga nasional, serta percepatan pertumbuhan, pengurangan ketimpangan dan penanggulangan kemiskinan.

Pembangunan ekonomi yang efisien menurut Jhingan (2014) membutuhkan suatu proses perencanaan yang teliti mengenai penggunaan sumberdaya publik dan sektor swasta (misalnya petani, pengusaha kecil, koperasi, pengusaha besar, organisasiorganisasi sosial) harus mempunyai peran dalam proses pembangunan. Perencanaan pembangunan sangat diperlukan untuk mengenyahkan kemiskinan bangsa. Perencanaan merupakan satu-satunya jalan yang terbuka bagi daerah terbelakang, untuk menaikkan pendapatan daerah dan pendapatan perkapita, untuk mengurangi ketimpangan 
pendapatan dan kesejahteraan, untuk meningkatkan kesempatan kerja, dan untuk pembangunan menyeluruh.

Strategi pembangunan daerah yang bertujuan meningkatkan pertumbuhan ekonomi daerah yang tercermin dalam dokumen perencanaan daerah, menurut Kuncoro (2012) diperlukan reorientasi strategi pembangunan daerah. Pertama, strategi pembangunan ekonomi lokal dengan pendekatan sektor unggulan daerah. Kedua, strategi pengembangan yang terintegrasi antara desa-kota dan jaringan antarkota. Ketiga, daya dorong (Big Push) modal dan infrastruktur pada daerah tertinggal. Keempat, visi dan strategi nasional percepatan pembangunan daerah yang terintegrasi antara Kabupaten, Kota dan Provinsi yang secara eksplisit dalam RPJMD.

Permasalahan dalam pembangunan ekonomi adalah bagaimana mencapai tingkat Gross National Product potensial yang tinggi. Menurut Malthus (1789) dalam Jhingan (2014) besarnya GNP potensial tergantung pada tanah, tenaga kerja, modal dan organisasi. Keempat faktor tersebut jika dipakai dalam proporsi yang benar, maka akan memaksimalkan produksi di dua sektor utama perekonomian yaitu: sektor pertanian dan sektor industri. Salah satu indikator penting untuk mengetahui laju pertumbuhan ekonomi di suatu daerah dalam suatu periode tertentu ditunjukkan oleh pertambahan Produk Domestik Regional Bruto (PDRB), baik atas dasar harga berlaku maupun atas dasar harga konstan. Perhitungan atas dasar harga konstan digunakan untuk mengetahui pertumbuhan ekonomi riil dari tahun ke tahun, dimana perubahan harga telah dikeluarkan (Widodo, 2006).

Tingkat pertumbuhan ekonomi tidak hanya bisa dilihat dari kondisi perekonomian secara keseluruhan akan tetapi harus juga dilihat pengaruh dari sektorsektor ekonomi yang ada di daerah tersebut, dimana sektor yang berpengaruh dominan disebut sektor unggulan. Pandangan dari teori basis ini menyatakan bahwa ekspor adalah salah satu cara dalam meningkatkan pembangunan daerah (Tarigan, 2014). Teori basis ekonomi ini dikemukakan oleh Richardson (1973) dalam Arsyad (2002) menyatakan bahwa faktor penentu utama pertumbuhan ekonomi suatu daerah adalah berhubungan langsung dengan permintaan akan barang dan jasa dari luar daerah. Asumsi ini memberikan pengertian bahwa suatu daerah akan mempunyai sektor unggulan apabila daerah tersebut dapat memenangkan persaingan pada sektor yang sama dengan daerah lain.

Menurut Ambardi \& Socia (2002) komoditas unggulan bisa menjadi motor penggerak pembangunan suatu daerah, diantaranya:

i. Komoditas unggulan harus mampu menjadi penggerak utama pembangunan perekonomian. Artinya komoditas unggulan dapat memberikan kontribusi yang signifikan pada peningkatan produksi, pendapatan, maupun pengeluaran.

ii. Komoditas unggulan mempunyai keterkaitan ke depan dan ke belakang yang kuat, baik sesama komoditas unggulan maupun komoditas lainnya.

iii. Komoditas unggulan mampu bersaing dengan produk sejenis dari wilayah lain di 
pasar nasional dan pasar internasional, baik dalam harga produk, biaya produksi, kualitas pelayanan, maupun aspek-aspek lainnya.

iv. Komoditas unggulan daerah memiliki keterkaitan dengan daerah lain, baik dalam hal pasar (konsumen) maupun pemasokan bahan baku (jika bahan baku di daerah sendiri tidak mencukupi atau tidak tersedia sama sekali).

v. Komoditas unggulan memiliki status teknologi yang terus meningkat, terutama melalui inovasi teknologi.

vi. Komoditas unggulan mampu menyerap tenaga kerja berkualitas secara optimal sesuai dengan skala produksinya.

vii. Komoditas unggulan bisa bertahan dalam jangka waktu tertentu, mulai dari fase kelahiran, pertumbuhan, puncak hingga penurunan. Begitu komoditas unggulan yang satu memasuki tahap penurunan, maka komoditas unggulan lainnya harus mempu menggantikannya.

viii. Komoditas unggulan tidak rentan terhadap gejolak eksternal dan internal.

ix. Pengembangan komoditas unggulan harus mendapatkan berbagai bentuk dukungan, misalkan dukungan keamanan, sosial, budaya, informasi dan peluang pasar, kelembagaan, fasilitas insentif/disintensif, dan lain-lain.

Mardiana, Budhi \& Swara (2017) dari hasil penelitiannya terhadap sektor unggulan dan pergeseran struktur ekonomi di Kabupaten Tabanan di Provinsi Bali menyimpulkan bahwa telah terjadi pergeseran sektor dari sektor pertanian ke sektor jasa. Sektor unggulan dan pergeseran struktur ekonomi di daerah memiliki peran yang penting dalam pembangunan daerah, dengan diketahuinya sektor-sektor unggulan dan perubahan struktur ekonomi akan bisa lebih memaksimalkan pembangunan daerah. Demikian juga Sawhney (2010) yang melakukan analisis terhadap pertumbuhan dan perubahan struktur perekonomian di negara-negara South Asian Association Regional Cooperation (SAARC) yang terdiri dari tujuh negara anggota, yaitu, Bangladesh, Bhutan, India, Maladewa, Nepal, Pakistan dan SriLanka selama dua dekade yaitu dari 1988 hingga 2008 yang menyimpulkan bawa pola telah terjadai trasformasi struktural ekonomi negara-negara SAARC dari sektor primer ke sektor tersier. Menurut Koncoro (2010) perubahan struktural menitikberatkan pembahasan pada mekanisme transformasi struktur ekonomi yang dialami oleh negara sedang berkembang, yang semula lebih bersifat subsistem dan menitikberatkan pada sektor pertanian menuju ke struktur perekonomian yang lebih modern, yang didominasi oleh sektor-sektor non primer. Transformasi struktur ekonomi ini terjadi pada sektor-sektor ekonomi yang ada pada daerah. Transformasi/pergeserannya bergeser dari sektor pertanian ke sektor-sektor ekonomi yang memberikan pendapatan yang lebih tinggi, sehingga dapat menunjang perekonomian pada suatu daerah.

Berdasarkan kajian teoritis dan empiris diatas, pengembangan perekonomian masyarakat diharapkan sesuai dengan arah kebijakan pembangunan daerah tertinggal yaitu pembangunan ekonomi yang dicapai bukan hanya dengan cara memanfaatkan potensi daerah secara optimal saja namun juga dengan memahami pergerakan struktural 
pembentukan PDRB daerah tertinggal. Dengan demikian strategi pembangunan daerah yang berlandaskan pertumbuhan ekonomi harus didukung oleh kebijakan yang mengarah pada pola pembangunan ekonomi dengan basis daerah melalui penentuan sektor ekonomi unggulan yaitu sektor yang tergolong kriteria sektor basis, sektor-sektor yang memilik daya saing yang tinggi (kompetitif) dan sektor yang tergolong maju dan tumbuh pesat.

\section{METODA PENELITIAN}

Penelitian ini bertujuan untuk mendeskripsikan penentuan sektor unggulan dan pergeseren struktural perekonomian yang akan dipergunakan sebagai informasi pengembangan sektor ekonomi pada daerah tertinggal di Provinsi Kalbar. Berdasarkan tujuan penelitian tersebut, maka bentuk penelitian yang digunakan adalah bentuk penelitian deskriptif.

Penelitian ini menggunakan data sekunder yaitu PDRB 8 (delapan) daerah tertinggal di Kalbar yaitu: Kabupaten Sambas, Kabupaten Bengkayang, Kabupaten Landak, Kabupaten Ketapang, Kabupaten Sintang, Kabupaten Kapuas Hulu, Kabupaten Melawi, dan Kabupaten Kayong Utara dan PDRB Provinsi Kalbar selama 5 (lima) tahun 2011-2015 yang bersumber dari Badan Pusat Statistik Provinsi Kalimantan Barat.

Alat analisis yang digunakan untuk menjawab permasalahan penelitian ini adalah:

\subsection{Analisis Shift Share}

Analisis Shift Share adalah salah satu teknik kuantitatif yang biasa digunakan untuk menganalisis perubahan struktur ekonomi daerah relatif terhadap struktur ekonomi wilayah administratif yang lebih tinggi sebagai pembanding atau referensi (Widodo, 2006). Hasil analisis Shift Share dalam penelitian ini akan menggambarkan kinerja (perubahan dan pergeseran) sektor-sektor dalam PDRB daerah tertinggal dibandingkan Provinsi Kalbar. Kemudian dilakukan analisis terhadap penyimpangan yang terjadi sebagai hasil perbandingan tersebut. Bila penyimpangan tersebut positif, maka dikatakan suatu sektor dalam PDRB daerah tertinggal memiliki keunggulan kompetitif atau sebaliknya.

Secara matematis Shift Share klasik dapat diformulasikan sebagai berikut (Suratman \& Wahyudi, 2009):

$\mathrm{D}_{\mathrm{ij}} \quad=\mathrm{N}_{\mathrm{ij}}+\mathrm{M}_{\mathrm{ij}}+\mathrm{C}_{\mathrm{ij}}$

$\mathrm{N}_{\mathrm{ij}} \quad=\mathrm{E}_{\mathrm{ij}} \times \mathrm{r}_{\mathrm{n}}$

$\mathrm{M}_{\mathrm{ij}} \quad=\mathrm{E}_{\mathrm{ij}}\left(\mathrm{r}_{\mathrm{in}}-\mathrm{r}_{\mathrm{n}}\right)$

$\mathrm{C}_{\mathrm{ij}} \quad=\mathrm{E}_{\mathrm{ij}}\left(\mathrm{r}_{\mathrm{ij}}-\mathrm{r}_{\mathrm{in}}\right)$

Dimana :

$\mathrm{D}_{\mathrm{ij}} \quad=$ Perubahan suatu variabel regional sektor $\mathrm{i}$ di wilayah $\mathrm{j}$.

$\mathrm{N}_{\mathrm{ij}} \quad=$ Komponen pertumbuhan nasional sektor $\mathrm{i}$ di wilayah $\mathrm{j}$.

$\mathrm{M}_{\mathrm{ij}} \quad=$ Bauran industri sektor $\mathrm{i}$ di wilayah $\mathrm{j}$. 
$\mathrm{C}_{\mathrm{ij}} \quad=$ Keunggulan kompetitif sektor $\mathrm{i}$ di wilayah $\mathrm{j}$.

$\mathrm{E}_{\mathrm{ij}} \quad=$ PDRB sektor $\mathrm{i}$ Kabupaten $\mathrm{j}$.

$r_{n} \quad=$ Laju pertumbuhan ekonomi Kalbar

$r_{\text {in }} \quad=$ Laju pertumbuhan sektor i Kalbar

$\mathrm{r}_{\mathrm{ij}} \quad=$ Laju pertumbuhan sektor $\mathrm{i}$ Kabupaten $\mathrm{j}$

\subsection{Analisis Location Quotient (LQ)}

Analisis Location Quotient (LQ) digunakan untuk menentukan sektor basis dan non basis pada daerah tertinggal di Kalbar. Metode LQ merupakan salah satu pendekatan yang umum digunakan dalam model ekonomi basis sebagai salah satu langkah untuk memahami sektor kegiatan dari PDRB daerah tertinggal yang menjadi pemicu pertumbuhan.

Untuk mendapatkan nilai LQ menggunakan formula sebagai berikut (Suratman \& Wahyudi, 2009):

$$
L Q=\frac{v_{i} / v_{t}}{V_{i} / V_{t}}
$$

dimana :

$\mathrm{V}_{\mathrm{i}} \quad=$ Output sektor $\mathrm{i}$ atau pendapatan industri daerah tertinggal.

$\mathrm{v}_{\mathrm{t}} \quad=$ Output total atau pendapatan total daerah tertinggal.

$\mathrm{V}_{\mathrm{i}} \quad=$ Output sektor $\mathrm{i}$ atau pendapatan industri provinsi Kalbar.

$\mathrm{V}_{\mathrm{t}} \quad=$ Output total atau pendapatan total provinsi Kalbar.

Ada tiga kondisi yang dapat dicirikan dari hasil perhitungan metode LQ pada suatu wilayah (Suratman \& Wahyudi, 2009), yaitu:

1) Nilai LQ > 1, maka sektor kegiatan tersebut merupakan sektor basis, artinya daerah bersangkutan disamping dapat memasok kebutuhan daerahnya juga mempunyai kecenderungan potensi ekspor ke daerah lain.

2) Nilai LQ $<1$, maka sektor kegiatan bersangkutan bukan sektor basis, artinya produk domestik tidak cukup untuk memenuhi kebutuhan daerah sendiri dan justru daerah bersangkutan memiliki kecenderungan untuk melakukan impor dari daerah lain.

3) Nilai $\mathrm{LQ}=1$, maka sektor kegiatan bersangkutan hanya dapat memenuhi kebutuhan daerahnya sendiri, produk domestik habis dikonsumsi daerah tersebut.

\subsection{Analisis Tipologi Klassen}

Tipologi Klassen merupakan salah satu alat analisis ekonomi regional yang dapat digunakan untuk mengetahui potensi ekonomi unggulan daerah tertinggal di Kalimantan Barat. Analisis Tipologi Klassen digunakan dengan tujuan mengidentifikasi posisi sektor perekonomian daerah tertinggal dengan memperhatikan sektor perekonomian Provinsi Kalbar sebagai daerah referensi. Analisis Tipologi Klassen menghasilkan empat klasifikasi sektor dengan karakteristik yang berbeda berikut (Sjafrizal, 2008), yaitu: 
1) Kuadran I, sektor yang maju dan tumbuh dengan pesat (developed sector).

2) Kuadran II, sektor maju tapi tertekan (stagnant sector).

3) Kuadran III, sektor potensial atau masih dapat berkembang (developing sector).

4) Kuadran IV, sektor relatif tertinggal (underdeveloped sector).

\section{HASIL PENELITIAN DAN PEMBAHASAN}

\subsection{Kontribusi Sektor Ekonomi}

Kontribusi perekonomian seluruh daerah tertinggal terhadap pembentukan PDRB Kalimantan Barat selama tahun 2011 sampai dengan 2015 rata-rata sebesar 47,64 persen, sedangkan keenam Kabupaten/Kota lain yang bukan termasuk kategori daerah tertinggal memiliki kontribusi yang lebih besar terhadap PDRB Kalbar yaitu dengan rata-rata sebesar 52,36 persen. Secara umum persentase ini dapat menggambarkan bahwa daerahdaerah tertinggal memang masih lemah dalam hal perekonomiannya. Kontribusi sektor ekonomi keseluruhan daerah tertinggal terhadap pembentukan PDRB Kalbar ini juga terus mengalami penurunan dari tahun 2011 yang semula rata-rata 48,11 persen menjadi 47,37 pada tahun 2015, dengan penurunan terjadi pada sebagian besar sektor perekonomian.

Struktur ekonomi daerah tertinggal di Provinsi Kalimantan Barat dapat dilihat dari besarnya peranan dari masing-masing sektor terhadap pembentukan PDRB. Struktur lapangan usaha atau sektor ekonomi sebagian masyarakat kalimantan barat masih didominasi oleh lapangan usaha pertanian, kehutanan dan perikanan dengan rata-rata kontribusi selama lima tahun terakhir adalah 32,20 persen diatas rata-rata Kalbar sebesar 23,76 persen. Hal ini berarti bahwa sektor pertanian, kehutanan dan perikanan merupakan sektor dominan kontributor pembentukan PDRB bagi sebagian besar daerah tertinggal di Provinsi Kalimantan Barat melebihi daerah-daerah lain yang bukan tergolong daerah tertinggal. Laju pertumbuhan sektor pertanian ini selama lima tahun terakhir mengalami pasang surut, namun kecenderungannya setiap tahun semakin menurun. Pada tahun 2012 laju pertumbuhan sektor ini sebesar 4,91 kemudian menurun menjadi 2,05 persen pada tahun 2015. Penurunan laju pertumbuhan dan kontribusi sektor pertanian ini mengindikasikan bahwa secara perlahan peranan sektor ekonomi di Kalimantan Barat telah mengalami pergeseran dari tradisional ke sektor ekonomi lainnya terutama sektor industri, perdagangan dan jasa.

Selain sektor pertanian, kehutanan dan perikanan, sektor perdagangan besar dan eceran, reparasi mobil dan sepeda motor menjadi sektor dengan tingkat kontribusi terbesar kedua pada sebagian besar daerah tertinggal dengan 14,85 persen terkecuali Ketapang dan Kapuas Hulu, namun kontribusi sektor ini masih dibawah rata-rata Kalbar sebesar 15,16 persen. Sektor ini kontribusinya cenderung meningkat dari tahun ke tahun yang semula pada tahun 2011 sebesar rata-rata 14,75 persen menjadi 15,19 persen pada tahun 2015. Demikian juga dengan laju pertumbuhannya yang setiap tahun cenderung meningkat dengan rata-rata sebesar 5,82 persen. 
Sektor industri pengolahan menjadi sektor ketiga berkontribusi terbesar pada perekonomian sebagian besar daerah tertinggal terkecuali Ketapang dengan sumbangan sebesar rata-rata 12,02 persen selama lima tahun terakhir, namun kontribusi sektor ini masih dibawah rata-rata Kalbar sebesar 16,91 persen. Tingkat kontribusi dan laju pertumbuhan sektor ini selama lima tahun terakhir cenderung menurun pada rata-rata daerah tertinggal di Kalbar. Sektor lain yang cukup besar berkontribusi pada rata-rata PDRB daerah tertinggal adalah sektor konstruksi dengan sumbangan 9,63 persen dan sektor pertambangan dan penggalian dengan 6,46 persen. Dominasi sektor pertambangan dan penggalian ini disebabkan adanya peningkatan ekploitasi berupa aktivitas penambangan biji logam pada beberapa daerah di Kalbar termasuk salah satunya di Kabupaten Ketapang, selain itu penambangan batu bara dan lignit serta pertambangan lainnya juga marak terjadi pada daerah lain di Kalbar.

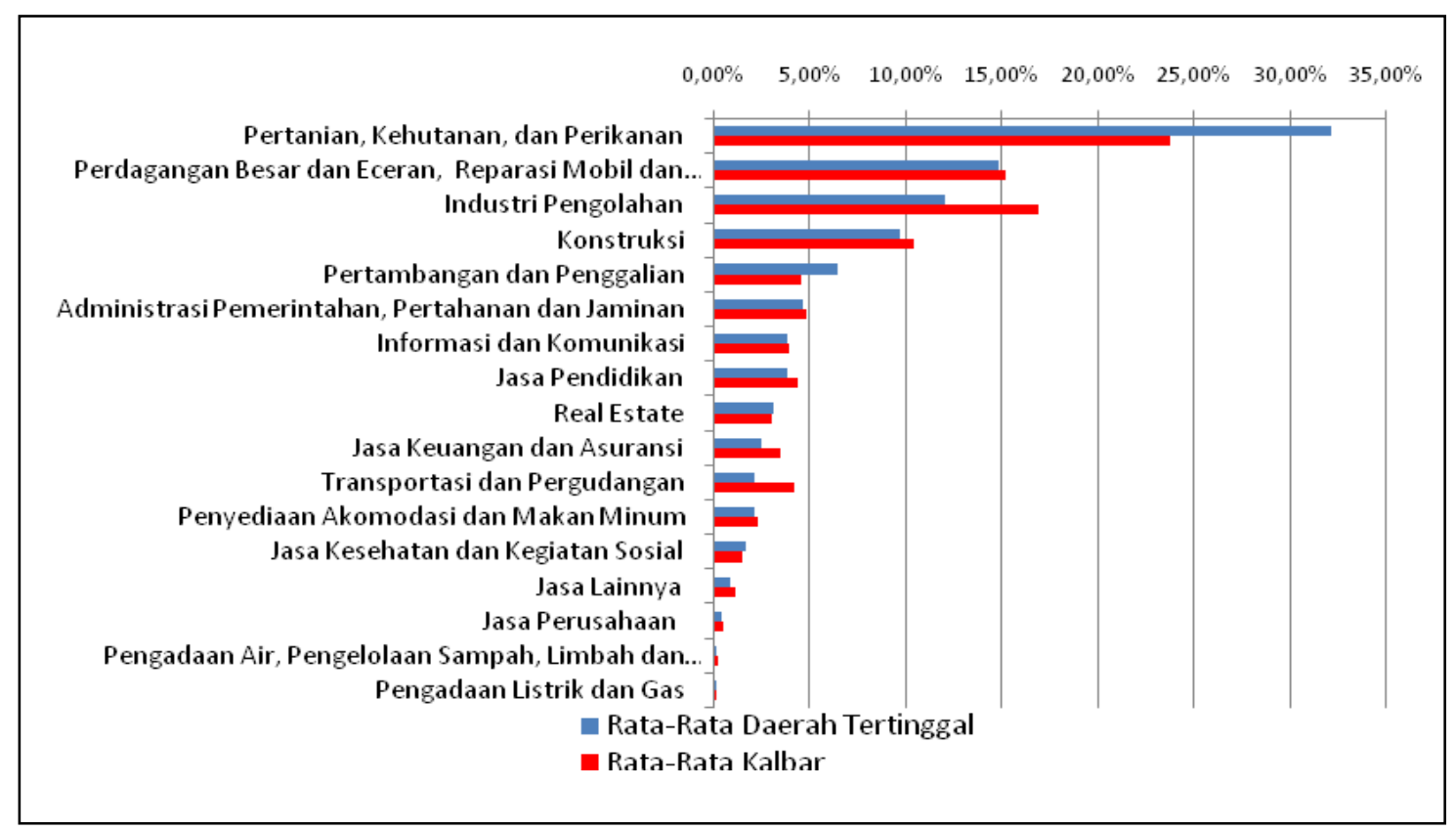

\section{Gambar 2. Kontribusi Per Sektor PDRB Rata-Rata Daerah Tertinggal dan Kontribusi Per Sektor PDRB Kalbar Tahun 2011-2015}

Selain ketiga sektor di atas hanya mampu berkontribusi pada PDRB daerahdaerah tertinggal rata-rata sebesar dibawah 5 persen dengan sektor ekonomi yang berkontribusi terkecil adalah sektor pengadaan listrik dan gas sebesar 0,03 persen dan sektor pengadaan air, pengelolaan sampah, limbah dan daur ulang sebesar 0,08 persen. Kondisi ini mengindikasikan bahwa sebagian besar daerah-daerah di Kalbar terutama daerah tertinggal masih mengalami keterbatasan atau masalah dengan pengelolaan sumber daya air dan listrik. Lemahnya pengelolaan sektor air dan listrik tentunya menjadi kelemahan bagi daerah-daerah tertinggal dalam upaya meningkatkan perekonomiannya terutama dalam usaha menarik perhatian investor untuk menanamkan 
modalnya di daerah-daerah tertinggal di Kalbar yang diperparah dengan kondisi infrastruktur yang belum memadai.

\subsection{Analisis Shift Share}

Hasil perhitungan nilai shift share terhadap rata-rata PDRB daerah tertinggal menunjukkan bahwa selama kurun waktu 2011-2015 mengalami pertambahan nilai absolut atau rata-rata daerah tertinggal mengalami kenaikan kinerja perekonomian sebesar Rp. 305,12 miliar. Hal ini dapat terlihat dari nilai Dij yang positif pada semua sektor ekonomi yang mempengaruhi peningkatan kinerja perekonomian daerah-daerah tertinggal selama lima tahun terakhir dan tidak terdapat sektor yang mengalami penurunan (negatif).

Demikian juga dengan hasil Shift Share yang dilakukan pada masing-masing PDRB daerah tertinggal yang menunjukkan kenaikan kinerja perekonomian pada seluruh daerah tertinggal. Hal ini berarti rata-rata peningkatan kinerja perekonomian seluruh daerah tertinggal selama lima tahun terakhir disumbangkan oleh seluruh sektor perekonomian pada rata-rata seluruh daerah tertinggal terkecuali sektor pertambangan dan penggalian pada PDRB Kabupaten Ketapang yang mengalami penyimpangan yang negatif.

Berdasarkan hasil perhitungan Shift Share, pada daerah-daerah tertinggal terdapat rata-rata 9 (sembilan) sektor ekonomi yang kompetitif, hal ini terlihat dari nilai Cij yang positif selama kurun waktu 2011-2015 yaitu sektor pengadaan air, pengelolaan sampah, limbah dan daur ulang, sektor perdagangan besar dan eceran, reparasi mobil dan sepeda motor, sektor tranportasi dan pergudangan, sektor penyediaan akomodasi dan makan minum, sektor jasa keuangan dan asuransi, sektor real estate, sektor jasa pendidikan, sektor jasa kesehatan dan kegiatan sosial serta yang terakhir sektor jasa lainnya. Kesembilan sektor perekonomian tersebut telah menunjukkan rata-rata tingkat daya saing yang semakin tinggi dibandingkan dengan sektor yang sama ditingkat perekonomian Provinsi Kalimantan Barat dalam periode pengamatan yang sama.

Hasil perhitungan Shift Share tersebut juga diketahui bahwa rata-rata sebagian sektor perekonomian pada daerah-daerah tertinggal sebanyak 8 (delapan) sektor mengalami penurunan tingkat daya saingnya yang terlihat dari nilai Cij yang negatif terhadap sektor yang sama pada Provinsi Kalbar yaitu sektor pertanian, kehutanan dan perikanan, sektor industri pengolahan, sektor pengadaan listrik dan gas, sektor konstruksi, sektor infomasi dan komunikasi, sektor jasa perusahaan, serta terakhir sektor administrasi pemerintahan, pertahanan dan jaminan. Dengan demikian, sektor-sektor perekonomian pada daerah-daerah tertinggal secara umum dalam periode pengamatan yang sama menunjukkan rata-rata tingkat keunggulan kompetitif yang lebih rendah dibandingkan dengan perekonomian Kalbar, hal ini terlihat dari jumlah nilai total Cij yang negatif, terkecuali untuk Kabupaten Bengkayang dan Sintang yang mempunyai nilai total $\mathrm{Cij}$ yang positif. 
Tabel 1. Hasil Perhitungan Nilai Shift Share PDRB Rata-Rata Daerah tertinggal

\begin{tabular}{|c|c|c|c|c|c|c|c|}
\hline \multirow{2}{*}{ No } & \multirow{2}{*}{ Lapangan Usaha } & \multicolumn{2}{|c|}{ Pertumbuhan } & \multicolumn{4}{|c|}{ Komponen (Jutaan Rupiah) } \\
\hline & & $\mathbf{S}$ & $\mathbf{S i}$ & $\mathbf{N i j}$ & Mij & $\mathbf{C i j}$ & Dij \\
\hline 1. & $\begin{array}{l}\text { Pertanian, Kehutanan, } \\
\text { dan Perikanan }\end{array}$ & 0,036 & 0,035 & $106.054,76$ & $\begin{array}{l}(35.396,51) \\
\end{array}$ & $(3.432,99)$ & $67.225,26$ \\
\hline 2. & $\begin{array}{l}\text { Pertambangan dan } \\
\text { Penggalian }\end{array}$ & 0,012 & 0,011 & $21.216,97$ & $(16.597,21)$ & $(417,42)$ & $4.202,34$ \\
\hline 3. & Industri Pengolahan & 0,046 & 0,039 & $39.626,05$ & $(5.887,69)$ & $(5.095,39)$ & $28.642,98$ \\
\hline 4. & $\begin{array}{l}\text { Pengadaan Listrik dan } \\
\text { Gas }\end{array}$ & 0,081 & 0,059 & 97,28 & 47,69 & $(39,95)$ & 105,02 \\
\hline 5. & $\begin{array}{l}\text { Pengadaan Air, } \\
\text { Pengelolaan Sampah, } \\
\text { Limbah dan Daur Ulang }\end{array}$ & 0,030 & 0,030 & 267,38 & $(122,62)$ & 4,78 & 149,54 \\
\hline 6. & Konstruksi & 0,100 & 0,093 & $31.902,81$ & $26.760,50$ & $(4.129,36)$ & $54.533,95$ \\
\hline 7. & $\begin{array}{l}\text { Perdagangan Besar dan } \\
\text { Eceran, Reparasi Mobil } \\
\text { dan Sepeda Motor }\end{array}$ & 0,055 & 0,058 & $49.026,20$ & 151,24 & $3.164,53$ & $52.341,97$ \\
\hline 8. & $\begin{array}{l}\text { Transportasi dan } \\
\text { Pergudangan }\end{array}$ & 0,058 & 0,062 & $6.855,28$ & 402,79 & 588,49 & $7.846,55$ \\
\hline 9. & $\begin{array}{l}\text { Penyediaan Akomodasi } \\
\text { dan Makan Minum }\end{array}$ & 0,058 & 0,063 & $6.743,88$ & 414,09 & 690,83 & $7.848,80$ \\
\hline 10. & $\begin{array}{l}\text { Informasi dan } \\
\text { Komunikasi }\end{array}$ & 0,118 & 0,101 & $12.710,88$ & $14.713,44$ & $(3.817,50)$ & $23.606,82$ \\
\hline 11. & $\begin{array}{l}\text { Jasa Keuangan dan } \\
\text { Asuransi }\end{array}$ & 0,096 & 0,112 & $7.974,69$ & $6.037,76$ & $2.411,19$ & $16.423,63$ \\
\hline 12. & Real Estate & 0,055 & 0,069 & $10.224,46$ & 137,91 & $2.582,40$ & $12.944,78$ \\
\hline 13. & Jasa Perusahaan & 0,072 & 0,061 & $1.333,64$ & 428,11 & $(264,50)$ & $1.497,24$ \\
\hline 14. & $\begin{array}{l}\text { Administrasi } \\
\text { Pemerintahan, } \\
\text { Pertahanan dan Jaminan }\end{array}$ & 0,051 & 0,041 & $15.223,13$ & $(859,68)$ & $(2.848,10)$ & $11.515,34$ \\
\hline 15. & Jasa Pendidikan & 0,048 & 0,049 & $12.398,45$ & $(1.470,16)$ & 137,61 & $11.065,91$ \\
\hline 16. & $\begin{array}{l}\text { Jasa Kesehatan dan } \\
\text { Kegiatan Sosial }\end{array}$ & 0,039 & 0,054 & $5.436,35$ & $(1.531,84)$ & $1.490,85$ & $5.395,35$ \\
\hline 17. & Jasa Lainnya & 0,032 & 0,041 & $2.798,92$ & $(1.179,71)$ & 462,11 & $2.081,32$ \\
\hline & JUMLAH & 0,054 & $\mathbf{0 , 0 5 0}$ & 329.891,14 & - & $(24.761,30)$ & $305.129,8$ \\
\hline
\end{tabular}

Output yang dihasilkan dari bauran industri (industri mix) dalam perekonomian rata-rata pada daerah tertinggal, sebagai hasil interaksi antar kegiatan industri dimana adanya aktivitas-aktivitas yang saling berhubungan satu sama lain dan menyerupai aktivitas-aktivitas yang lain sebagian besar berdampak positif yang terlihat pada nilai Mij yang positif pada 9 (sembilan) sektor yaitu terhadap sektor pengadaan listrik dan gas, sektor kontruksi, sektor perdagangan besar dan eceran, reparasi mobil dan sepeda motor, sektor transportasi dan pergudangan, sektor penyediaan akomodasi dan makan minum, sektor informasi dan komunikasi, sektor jasa keuangan dan asuransi, sektor real estate dan jasa perusahaan. Namun pada periode pengamatan yang sama, perekonomian rata- 
rata daerah tertinggal juga terdapat sektor yang memiliki bauran industri yang negatif yang ditunjukkan dengan nilai Mij yang negatif (8 sektor).

Hasil perhitungan pada rata-rata daerah tertinggal ini sejalan dengan hasil perhitungan shift share untuk masing-masing daerah tertinggal yang menunjukkan hasil yang sama dimana semua daerah tertinggal mempunyai bauran industri yang positif pada 9 (sembilan) sektor perekonomian yaitu sektor pengadaan listrik dan gas, sektor kontruksi, sektor perdagangan besar dan eceran, reparasi mobil dan sepeda motor, sektor transportasi dan pergudangan, sektor penyediaan akomodasi dan makan minum, sektor informasi dan komunikasi, sektor jasa keuangan dan asuransi, sektor real estate dan jasa perusahaan.

Pertumbuhan ekonomi Kalimantan Barat yang menunjukkan bagaimana pengaruh pertumbuhan ekonomi Kalbar terhadap perekonomian daerah-daerah tertinggal menunjukkan nilai positif (Nij) pada semua sektor ekonomi dengan total nilai output Rp.329,89 miliar. Sedangkan jika dilihat dari aspek tingkat pertumbuhan ekonomi sektoral rata-rata daerah tertinggal dibandingkan dengan tingkat pertumbuhan relatif sektor-sektor ekonomi yang sama di Provinsi Kalbar, menunjukkan bahwa sebagian besar tingkat pertumbuhan sektor ekonomi pada daerah-daerah tertinggal masih relatif sedikit lebih rendah dibandingkan pertumbuhan sektor ekonomi yang sama pada PDRB Provinsi Kalbar, kecuali untuk sektor perdagangan besar dan eceran, reparasi mobil dan sepeda motor, sektor transportasi dan pergudangan, sektor penyediaan akomodasi dan makan minum, sektor jasa keuangan dan asuransi, sektor real estate, sektor jasa pendidikan, sektor jasa kesehatan dan kegiatan sosial serta yang terakhir sektor jasa lainnya.

Hasil perhitungan shift share ini juga menunjukkan bahwa diantara delapan daerah tertinggal hanya Kabupaten Bengkayang dan Kabupaten Sintang yang memilki rata-rata pertumbuhan sektoral yang lebih baik dari rata-rata pertumbuhan sektoral Provinsi Kalimantan Barat. Namun secara keseluruhan, sektor ekonomi baik rata-rata daerah tertinggal maupun sektor ekonomi Provinsi Kalbar mengalami tingkat pertumbuhan yang positif dengan tingkat pertumbuhan ekonomi yang masih relatif berimbang yaitu hanya berselisih sebesar 0,004 persen.

\subsection{Analisis Location Quotient (LQ)}

Berdasarkan hasil perhitungan LQ pada daerah tertinggal kurun waktu 20112015, rata-rata daerah tertinggal hanya terdapat 4 (empat) sektor yang merupakan sektor basis yang ditunjukkan dengan nilai LQ lebih dari 1 (LQ > 1), yaitu sektor pertanian, kehutanan dan perikanan, sektor pertambangan dan penggalian, sektor real estate dan terakhir sektor jasa kesehatan dan kegiatan sosial. Sementara itu sebagian besar 13 (tiga belas) sektor ekonomi lainnya pada sebagian besar daerah tertinggal menunjukkan nilai LQ rata-rata di bawah 1 (LQ < 1), hal ini berarti produk domestik dari sektor ini tidak cukup atau belum mampu untuk memenuhi kebutuhan rata-rata pada daerah tertinggal 
dan justru daerah-daerah tertinggal memiliki kecenderungan untuk melakukan impor dari daerah lainnya.

Tabel 2. Hasil Perhitungan Indeks Location Quotient (LQ) Daerah Tertinggal

\begin{tabular}{|c|c|c|c|c|c|c|c|c|c|}
\hline \multirow{2}{*}{$\begin{array}{l}\text { Sek- } \\
\text { tor }\end{array}$} & \multicolumn{8}{|c|}{ Kabupaten } & \multirow{2}{*}{$\begin{array}{c}\text { Rata- } \\
\text { Rata } \\
\text { Daerah } \\
\text { Tertingg } \\
\quad \text { al }\end{array}$} \\
\hline & Sambas & $\begin{array}{l}\text { Beng- } \\
\text { kayang }\end{array}$ & Landak & Ketapang & Sintang & $\begin{array}{c}\text { K. } \\
\text { Hulu }\end{array}$ & Melawi & $\begin{array}{c}\mathrm{K} . \\
\text { Utara }\end{array}$ & \\
\hline S1 & B & B & B & B & B & B & B & B & $\mathrm{B}$ \\
\hline $\mathrm{S} 2$ & N B & $\mathrm{NB}$ & N B & B & B & B & B & N B & B \\
\hline S3 & N B & N B & $\mathrm{NB}$ & N B & N B & N B & N B & N B & N B \\
\hline S4 & N B & N B & $\mathrm{NB}$ & N B & N B & N B & N B & N B & N B \\
\hline S5 & N B & N B & N B & N B & N B & N B & N B & $\mathrm{B}$ & N B \\
\hline S6 & N B & N B & N B & N B & N B & B & B & N B & N B \\
\hline S7 & $\mathrm{B}$ & $\mathrm{B}$ & N B & $\mathrm{NB}$ & B & N B & $\mathrm{B}$ & N B & N B \\
\hline S8 & N B & N B & N B & N B & N B & N B & N B & N B & N B \\
\hline S9 & N B & $\mathrm{NB}$ & B & N B & B & N B & B & N B & N B \\
\hline S10 & $\mathrm{B}$ & B & N B & N B & B & N B & B & B & N B \\
\hline S11 & N B & N B & N B & N B & N B & N B & N B & N B & N B \\
\hline S12 & B & B & B & N B & N B & N B & B & B & B \\
\hline S13 & N B & N B & N B & $\mathrm{NB}$ & N B & $\mathrm{B}$ & N B & N B & N B \\
\hline S14 & N B & $\mathrm{B}$ & $\mathrm{B}$ & $\mathrm{NB}$ & N B & B & $\mathrm{B}$ & $\mathrm{B}$ & $\mathrm{NB}$ \\
\hline $\mathrm{S} 15$ & $\mathrm{~B}$ & N B & N B & N B & B & N B & $\mathrm{B}$ & N B & N B \\
\hline S16 & N B & B & B & N B & B & B & B & B & B \\
\hline S17 & N B & N B & N B & N B & N B & N B & B & B & N B \\
\hline
\end{tabular}

Keterangan: B: Basis, NB: Non Basis, S1: Sektor Pertanian, Kehutanan dan Perikanan, S2: Sektor Pertambangan dan Penggalian, S3: Sektor Industri dan Pengolahan, S4: Sektor Pengadaan Listrik dan Gas, S5: Sektor Pengadaan Air, Pengelolaan Sampah, Limbah dan Daur Ulang, S6: Sektor Konstruksi, S7: Sektor Perdagangan Besar dan Eceran, Reparasi Mobil dan Sepeda Motor, S8: Sektor Transportasi dan Pergudangan, S9: Sektor Penyediaan Akomodasi dan Makan Minum, S10: Sektor Informasi dan Komunikasi, S11: Sektor Jasa Keuangan dan Asuransi, S12: Sektor Real Estate, S13: Sektor Jasa Perusahaan, S14: Sektor Administrasi Pemerintahan, Pertahanan dan Jaminan, S15: Sektor Jasa Pendidikan, S16: Sektor Jasa Kesehatan dan Kegiatan Sosial dan S17: Sektor Jasa Lainnya.

Hasil perhitungan LQ pada tabel 2 menunjukkan bahwa di Kalbar, sektor pertanian, kehutanan dan perikanan merupakan sektor basis pada seluruh daerah tertinggal di 8 (delapan) Kabupaten, sedangkan sektor jasa kesehatan dan kegiatan sosial merupakan sektor basis terbanyak kedua yang berada pada 6 (enam) daerah tertinggal. Dengan demikian sektor-sektor basis tersebut sudah mampu memenuhi kebutuhan masyarakat daerah-daerah tertinggal sendiri dan potensial untuk di pasarkan (eksport) ke daerah lain di Kalimantan Barat. Sedangkan sektor lainnya hanya mampu memenuhi 
kebutuhan untuk di daerah tertinggal sendiri atau belum dapat memenuhi kebutuhan daerah tertinggal sendiri, sehingga perlu masukan (import) dari daerah lain.

\subsection{Analisis Tipologi Klassen}

Hasil klasifikasi sektor (Tipologi Klassen) total PDRB daerah tertinggal berdasarkan hasil pengolahan data berupa rata-rata pertumbuhan dan rata-rata kontribusi sektor PDRB Provinsi Kalbar dan PDRB rata-rata daerah tertinggal kurun waktu 20112015, menunjukkan bahwa sebagian besar daerah tertinggal terdapat 2 (dua) sektor prima yang merupakan sektor maju dan tumbuh pesat (develoved sector) yaitu sektor real estate dan sektor jasa kesehatan dan kegiatan sosial.

Tabel 3. Klasifikasi Sektor Berdasarkan Tipologi Klassen PDRB Daerah Tertinggal

\begin{tabular}{|c|c|c|c|c|c|c|c|c|c|}
\hline \multirow[b]{2}{*}{$\begin{array}{l}\text { Sek- } \\
\text { tor }\end{array}$} & \multicolumn{8}{|c|}{ Kabupaten } & \multirow{2}{*}{$\begin{array}{c}\text { Rata- } \\
\text { Rata } \\
\text { Daerah } \\
\text { Terting- } \\
\text { gal }\end{array}$} \\
\hline & Sambas & $\begin{array}{c}\text { Bengka- } \\
\text { yang }\end{array}$ & Landak & $\begin{array}{l}\text { Keta- } \\
\text { pang }\end{array}$ & Sintang & $\begin{array}{c}\text { K. } \\
\text { Hulu }\end{array}$ & Melawi & $\begin{array}{c}\mathrm{K} . \\
\text { Utara }\end{array}$ & \\
\hline $\mathrm{S} 1$ & K 1 & K 2 & K 1 & K 2 & K 2 & K 2 & K 2 & K 1 & K 2 \\
\hline S2 & K 3 & K 3 & K 3 & K 2 & K 1 & K 1 & K 1 & K 3 & K 2 \\
\hline S3 & K 4 & K 4 & K 4 & K 4 & K 4 & K 4 & K 3 & K 4 & K 4 \\
\hline S4 & K 4 & K 4 & K 4 & K 4 & K 4 & K 4 & K 4 & K 4 & K 4 \\
\hline S5 & K 4 & K 3 & K 3 & K 4 & K 3 & K 4 & K 3 & K 1 & K 3 \\
\hline S6 & K 3 & K 4 & K 4 & K 4 & K 3 & K 2 & K 2 & K 4 & K 4 \\
\hline S7 & K 2 & K 1 & K 3 & K 3 & K 2 & K 4 & K 2 & K 3 & K 3 \\
\hline S8 & K 4 & K 3 & K 3 & K 3 & K 3 & K 4 & K 3 & K 3 & K 3 \\
\hline S9 & K 3 & K 4 & K 1 & K 3 & K 2 & K 4 & K 2 & K 3 & K 3 \\
\hline $\mathrm{S} 10$ & K 2 & K 2 & K 4 & K 4 & K 1 & K 4 & K 2 & K 2 & K 4 \\
\hline S11 & K 3 & K 4 & K 3 & K 3 & K 3 & K 4 & K 4 & K 3 & K 3 \\
\hline S12 & K 1 & K 1 & K 1 & K 3 & K 3 & K 3 & K 1 & K 1 & K 1 \\
\hline S13 & K 4 & K 4 & K 4 & K 3 & K 4 & K 2 & K 4 & K 4 & K 4 \\
\hline S14 & K 4 & K 2 & K 2 & K 3 & K 4 & K 2 & K 2 & K 1 & K 4 \\
\hline S15 & K 1 & K 4 & K 3 & K 4 & K 2 & K 4 & K 1 & K 3 & K 3 \\
\hline S16 & K 3 & K 1 & K 1 & K 3 & K 1 & K 1 & K 1 & K 1 & K 1 \\
\hline S17 & K 3 & K 3 & K 3 & K 3 & K 3 & K 3 & K 1 & K 1 & K 3 \\
\hline
\end{tabular}

Keterangan: K1: Kuadran I (Prima), K2: Kuadran II (Potensial), K3: Kuadran III (Berkembang), K4: Kuadran IV (Terbelakang), S1: Sektor Pertanian, Kehutanan dan Perikanan, S2: Sektor Pertambangan dan Penggalian, S3: Sektor Industri dan Pengolahan, S4: Sektor Pengadaan Listrik dan Gas, S5: Sektor Pengadaan Air, Pengelolaan Sampah, Limbah dan Daur Ulang, S6: Sektor Konstruksi, S7: Sektor Perdagangan Besar dan Eceran, Reparasi Mobil dan Sepeda Motor, S8: Sektor Transportasi dan Pergudangan, S9: Sektor Penyediaan Akomodasi dan Makan Minum, S10: Sektor Informasi dan Komunikasi, S11: Sektor Jasa Keuangan dan Asuransi, S12: Sektor Real Estate, S13: Sektor Jasa Perusahaan, S14: Sektor Administrasi Pemerintahan, Pertahanan dan Jaminan, S15: Sektor Jasa Pendidikan, S16: Sektor Jasa Kesehatan dan Kegiatan Sosial dan S17: Sektor Jasa Lainnya. 
Sektor yang potensial atau sektor maju tetapi tertekan (stagnant sector) pada PDRB rata-rata daerah tertinggal selama periode pengamatan juga terdapat 2 (dua) sektor yaitu sektor pertanian, kehutanan dan perikanan serta sektor pertambangan dan penggalian. Sektor-sektor potensial ini memiliki rata-rata tingkat pertumbuhan yang lebih kecil dibandingkan rata-rata tingkat pertumbuhan sektor sama pada PDRB Kalbar namun memiliki kelebihan berupa kontribusi yang lebih besar dibandingkan kontribusi sektor yang sama pada PDRB Kalbar.

Hasil klasifikasi sebagian besar PDRB daerah tertinggal terdapat 7 (tujuh) sektor yang masih dapat berkembang (developing sector) yaitu sektor pengadaan air, pengelolaan sampah, limbah dan daur ulang, sektor perdagangan besar dan eceran, reparasi mobil dan sepeda motor, sektor transportasi dan pergudangan, sektor penyediaan akomodasi dan makan minum, sektor jasa keuangan dan asuransi, sektor jasa pendidikan dan sektor jasa lainnya. Ketujuh sektor berkembang pada rata-rata daerah tertinggal ini mempunyai kelebihan berupa rata-rata pertumbuhannya yang lebih besar dari pada pertumbuhan sektor yang sama pada PDRB Kalbar, namun rata-rata kontribusinya masih kecil terhadap sektor yang sama pada PDRB Kalbar.

Dari hasil klasifikasi di atas juga ternyata sebagian besar rata-rata sektor ekonomi daerah tertinggal termasuk sektor ekonomi terbelakang yang merupakan sektor relatif tertinggal (undeveloved sector) yaitu hanya sebanyak 6 (enam) sektor. Sektor-sektor ini memiliki pertumbuhan dan kontribusi yang lebih kecil dari pertumbuhan dan kontribusi sektor yang sama pada PDRB Kalbar. Adapun sektor tersebut adalah sektor industri pengolahan, sektor pengadaan listrik dan gas, sektor konstruksi, sektor informasi dan komunikasi, sektor jasa perusahaan dan sektor administrasi pemerintahan, pertahanan dan jaminan.

\subsection{Sektor Unggulan Daerah Tertinggal}

Penentuan sektor unggulan rata-rata pada daerah tertinggal dilakukan dengan menggabungkan tiga hasil analisis yaitu analisis Shift Share, analisis Location Quotient (LQ) dan analisis Tipologi Klassen. Berdasarkan tabel 4 bahwa pada perekonomian ratarata daerah tertinggal selama periode pengamatan tahun 2011 sampai dengan 2015 terdapat 2 (dua) sektor ekonomi unggulan atau sektor ekonomi yang tergolong kriteria sektor basis, sektor yang memilik daya saing yang tinggi (kompetitif) dan tergolong sektor yang maju dan tumbuh pesat. Adapun kedua sektor yang tergolong sektor unggulan tersebut yaitu sektor real estate dan sektor jasa kesehatan dan kegiatan sosial.

Selain sektor unggulan tesebut di atas, juga terdapat 2 (dua) sektor yang termasuk sektor basis namun pertumbuhannya masih tertekan yang berpotensi untuk menjadi sektor yang maju dan tumbuh pesat kedepannya pada rata-rata daerah tertinggal yaitu sektor pertanian, kehutanan dan perikanan dan sektor pertambangan dan penggalian. Sedangkan sektor-sektor yang lain merupakan sektor yang masih dapat berkembang dan sektor yang relatif tertinggal di daerah tertinggal di Kalbar. 
Tabel 4. Hasil Penentuan Sektor Unggulan PDRB Rata-Rata Daerah Tertinggal

\begin{tabular}{|c|c|c|c|c|c|}
\hline No. & Sektor Perekonomian & $\begin{array}{l}\text { Shift Share } \\
\text { (Cij) }\end{array}$ & LQ & $\begin{array}{l}\text { Tipologi } \\
\text { Klassen }\end{array}$ & Keterangan \\
\hline 1. & $\begin{array}{l}\text { Pertanian, Kehutanan, dan } \\
\text { Perikanan }\end{array}$ & Negatif & Basis & Potensial & Non Unggulan \\
\hline 2. & Pertambangan dan Penggalian & Negatif & Basis & Potensial & Non Unggulan \\
\hline 3. & Industri Pengolahan & Negatif & Non Basis & Terbelakang & Non Unggulan \\
\hline 4. & Pengadaan Listrik dan Gas & Negatif & Non Basis & Terbelakang & Non Unggulan \\
\hline 5. & $\begin{array}{l}\text { Pengadaan Air, Pengelolaan } \\
\text { Sampah, Limbah dan Daur } \\
\text { Ulang }\end{array}$ & Positif & Non Basis & Berkembang & Non Unggulan \\
\hline 6. & Konstruksi & Negatif & Non Basis & Terbelakang & Non Unggulan \\
\hline 7. & $\begin{array}{l}\text { Perdagangan Besar dan } \\
\text { Eceran, Reparasi Mobil dan } \\
\text { Sepeda Motor }\end{array}$ & Positif & Non Basis & Berkembang & Non Unggulan \\
\hline 8. & Transportasi dan Pergudangan & Positif & Non Basis & Berkembang & Non Unggulan \\
\hline 9. & $\begin{array}{l}\text { Penyediaan Akomodasi Dan } \\
\text { Makan Minum }\end{array}$ & Positif & Non Basis & Berkembang & Non Unggulan \\
\hline 10. & Informasi dan Komunikasi & Negatif & Non Basis & Terbelakang & Non Unggulan \\
\hline 11. & Jasa Keuangan dan Asuransi & Positif & Non Basis & Berkembang & Non Unggulan \\
\hline 12. & Real Estate & Positif & Basis & Prima & Unggulan \\
\hline 13. & Jasa Perusahaan & Negatif & Non Basis & Terbelakang & Non Unggulan \\
\hline 14. & $\begin{array}{l}\text { Administrasi Pemerintahan, } \\
\text { Pertahanan dan Jaminan }\end{array}$ & Negatif & Non Basis & Terbelakang & Non Unggulan \\
\hline 15. & Jasa Pendidikan & Positif & Non Basis & Berkembang & Non Unggulan \\
\hline 16. & $\begin{array}{l}\text { Jasa Kesehatan dan Kegiatan } \\
\text { Sosial }\end{array}$ & Positif & Basis & Prima & Unggulan \\
\hline 17. & Jasa Lainnya & Positif & Non Basis & Berkembang & Non Unggulan \\
\hline
\end{tabular}

\section{i. $\quad$ Sektor Real Estate}

Sektor real estate mempunyai peran yang kecil terhadap pembentukan PDRB pada rata-rata daerah tertinggal namun kontribusinya terus mengalami peningkatan selama 5 tahun terakhir. Kontribusi sektor ini hanya mencapai 3,09 persen sedikit melebihi rata-rata kontribusi ditingkat Provinsi Kalbar dengan 3.00 persen dan menempati urutan kedelapan dalam kontribusinya terhadap PDRB rata-rata daerah tertinggal. Daerah tertinggal dengan kontribusi terbesar dari sektor ini adalah Kabupaten Melawi dengan rata-rata 5,01 persen, sedangkan Kabupaten Ketapang merupakan kontributor sektor terkecil untuk sektor ini diantara daerah tertinggal yang lain dengan 2.55 persen. 


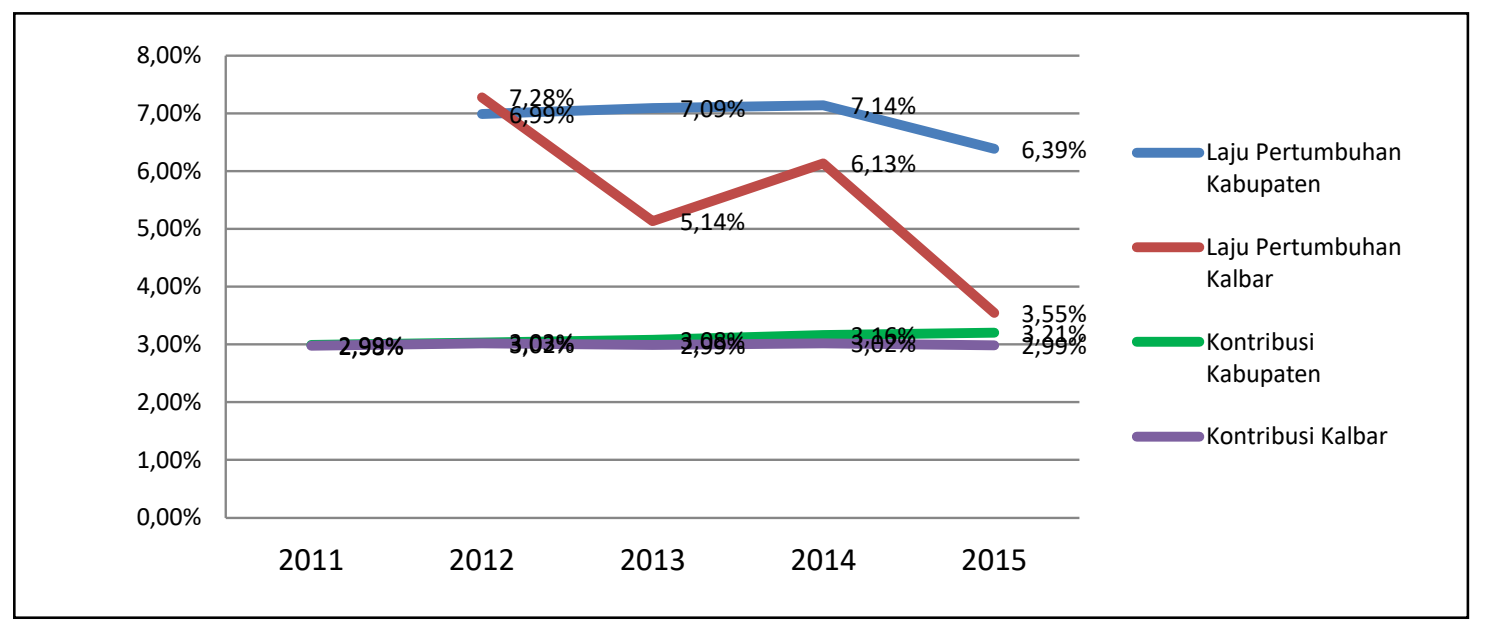

\section{Gambar 3. Grafik Laju Pertumbuhan dan Kontribusi Sektor Real Estate Rata-Rata Daerah Tertinggal dan Provinsi Kalbar}

Laju pertumbuhan sektor ini mengalami pasang surut selama lima tahun terakhir dengan rata-rata pertumbuhan sebesar 6,90 persen melebihi laju pertumbuhan di tingkat Provinsi Kalbar dengan rata-rata 5,52 persen, sehingga sektor ini diklasifikasikan sebagai sektor yang maju dan tumbuh pesat (prima). Adapun daerah tertinggal dengan rata-rata tingkat pertumbuhan tertinggi pada sektor ini adalah Kabupaten Ketapang dengan 9,29 persen dan Kabupaten Sambas merupakan daerah dengan pertumbuhan terendah sebesar 5,87 persen.

Sektor real estate ini merupakan salah satu penyumbang terjadinya peningkatan kinerja perekonomian pada rata-rata daerah tertinggal dengan pertambahan nilai absolut sebesar Rp.12,94 miliar. Sektor ini juga memiliki daya saing (kompetitif) yang lebih tinggi dari sektor yang sama pada PDRB Kalbar selama kurun waktu lima tahun terakhir yang ditunjukkan dengan nilai pergeseran diferensial (differential shift) positif sebesar Rp.2,58 miliar. Demikian juga dengan hasil perhitungan analisis LQ untuk Sektor ini sebesar rata-rata 1,03 yang berarti bahwa sektor ini merupakan sektor basis yang sudah mampu memenuhi kebutuhan masyarakat pada rata-rata daerah tertinggal sendiri dan sangat potensial untuk dipasarkan (eksport) ke daerah lain.

ii. Sektor Jasa Kesehatan dan Kegiatan Sosial

Sektor jasa kesehatan dan kegiatan sosial ini juga mempunyai pengaruh yang kecil terhadap pembentukan PDRB pada rata-rata daerah tertinggal, hal ini ditunjukkan dengan rata-rata kontribusi sektor ini yang hanya mencapai 1,65 persen sedikit melebihi rata-rata kontribusi ditingkat Provinsi Kalbar dengan 1,48 persen dan menempati urutan kesepuluh dalam kontribusinya terhadap PDRB rata-rata daerah tertinggal. Daerah tertinggal dengan tingkat kontribusi terbesar dari sektor ini adalah Kabupaten Melawi dengan rata-rata 5,01 persen, sedangkan Kabupaten Ketapang merupakan kontributor terkecil untuk sektor ini diantara daerah tertinggal yang lain dengan 2.55 persen. 


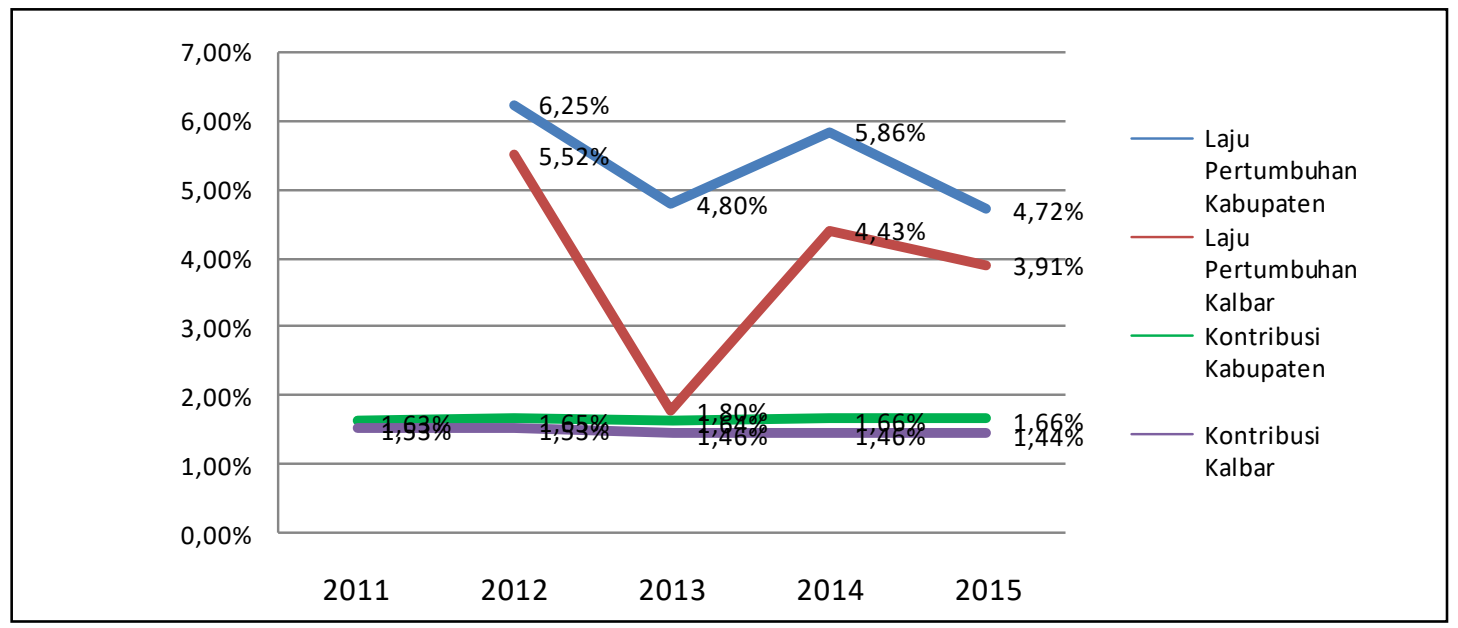

\section{Gambar 4. Grafik Laju Pertumbuhan dan Kontribusi Sektor Jasa Kesehatan dan Kegiatan Sosial Rata-Rata Daerah Tertinggal dan Provinsi Kalbar}

Laju pertumbuhan sektor ini terus mengalami penurunan selama lima tahun terakhir dengan rata-rata pertumbuhan sektor sebesar 5,41 persen melebihi laju pertumbuhan di tingkat Provinsi Kalbar dengan rata-rata 3,91 persen, sehingga sektor ini diklasifikasikan sebagai sektor yang maju dan tumbuh pesat (prima). Adapun daerah tertinggal dengan rata-rata tingkat pertumbuhan tertinggi pada sektor ini adalah Kabupaten Melawi dengan 6,77 persen dan Kabupaten Bengkayang merupakan daerah dengan pertumbuhan terendah sebesar 4,72 persen. Sektor real estate ini juga merupakan salah satu penyumbang terjadinya peningkatan kinerja perekonomian pada rata-rata daerah tertinggal dengan pertambahan nilai absolut sebesar Rp.5,39 miliar. Sektor ini juga memiliki daya saing (kompetitif) yang lebih tinggi dari sektor yang sama pada PDRB Kalbar selama kurun waktu lima tahun terakhir yang ditunjukkan dengan nilai pergeseran diferensial (differential shift) positif sebesar Rp.1,49 miliar. Demikian juga dengan hasil perhitungan analisis LQ untuk Sektor ini sebesar rata-rata 1,11 yang berarti bahwa sektor ini merupakan sektor basis yang sudah mampu memenuhi kebutuhan masyarakat pada rata-rata daerah tertinggal sendiri dan sangat potensial untuk dipasarkan (eksport) ke daerah lain.

iii. Pertanian, Kehutanan dan Perikanan

Sektor pertanian, kehutanan dan perikanan ini mempunyai kontribusi yang sangat besar terhadap pembentukan PDRB pada rata-rata daerah tertinggal. hal ini ditunjukkan dengan rata-rata kontribusi sektor ini yang mencapai 32,20 persen sedikit melebihi ratarata kontribusi sektor yang sama ditingkat Provinsi Kalbar dengan 23,76 persen dan merupakan kontributor tertinggi dalam terhadap pembentukan PDRB pada rata-rata daerah tertinggal. Daerah tertinggal dengan tingkat kontribusi terbesar pada pembentukan PDRB nya dari sektor pertanian, kehutanan dan perikanan ini adalah Kabupaten Landak dengan rata-rata 37,92 persen, sedangkan Kabupaten Melawi merupakan kontributor terkecil untuk sektor ini diantara daerah tertinggal yang lain dengan 24,73 persen. seperti yang ditunjukkan pada gambar 5, persentase kontribusi 
sektor pertanian, kehutanan dan perikanan pada rata-rata daerah tertinggal selama lima tahun terakhir terus mengalami penurunan dari 32,90 persen pada tahun 2011 menjadi 30,95 persen pada tahun 2015 .

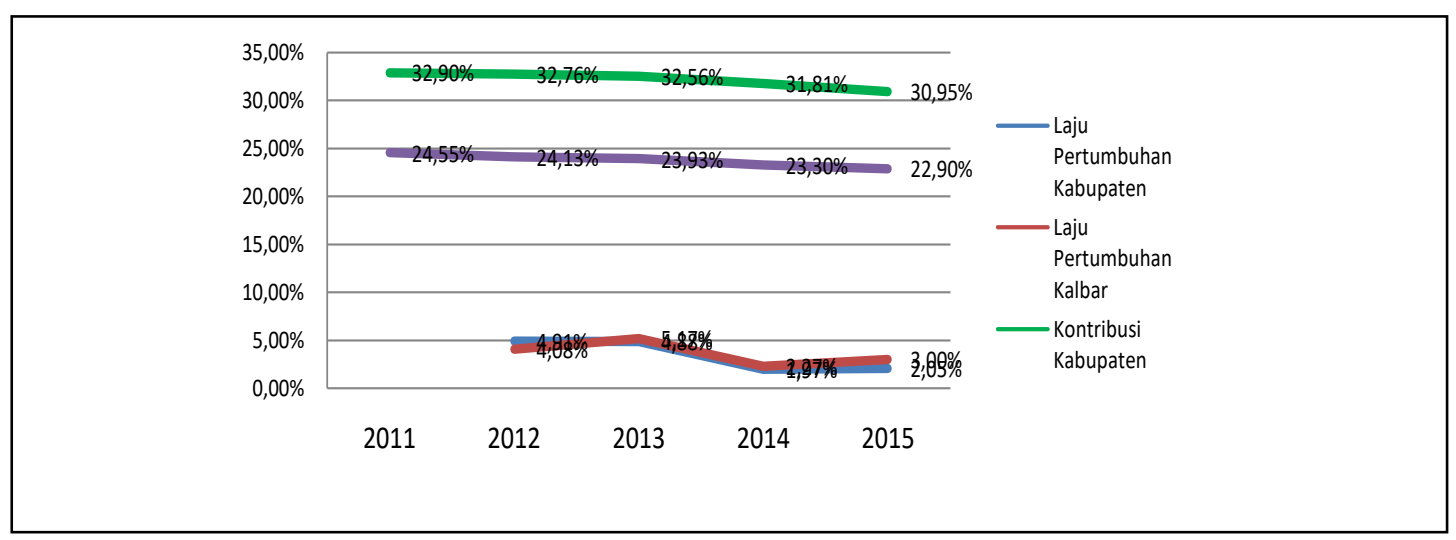

Gambar 5. Grafik Laju Pertumbuhan dan Kontribusi Sektor Pertanian, Perikanan dan Kehutanan Rata-Rata Daerah Tertinggal dan Provinsi Kalbar

Demikian juga dengan laju pertumbuhan sektor ini yang terus mengalami penurunan selama lima tahun terakhir dengan rata-rata pertumbuhan sektor sebesar 3,45 persen namun masih dibawah laju pertumbuhan sektor yang sama PDRB Provinsi Kalbar dengan rata-rata 3,63 persen, sehingga sektor ini diklasifikasikan sebagai sektor yang maju dan namun pertumbuhannya masih tertekan (potensial). Adapun daerah tertinggal dengan rata-rata tingkat pertumbuhan tertinggi untuk sektor ini adalah Kabupaten Sambas dengan 4,19 persen dan Kabupaten Kapuas Hulu merupakan daerah dengan ratarata tingkat pertumbuhan terendah dengan 2,42 persen.

Sektor pertanian, perikanan dan kehutanan ini juga merupakan penyumbang terbesar terjadinya peningkatan kinerja perekonomian pada rata-rata daerah tertinggal dengan pertambahan nilai absolut sebesar Rp.67,22 miliar. Namun sektor ini memiliki daya saing (kompetitif) yang lebih rendah dari sektor yang sama pada PDRB Kalbar selama kurun waktu lima tahun terakhir yang ditunjukkan dengan nilai pergeseran diferensial (differential shift) negatif sebesar Rp.3,43 miliar. Sedangkan dengan hasil perhitungan analisis LQ untuk sektor pertanian, kehutanan dan perikanan ini sebesar rata-rata 1,36 yang berarti bahwa sektor ini merupakan sektor basis yang sudah mampu memenuhi kebutuhan masyarakat pada rata-rata daerah tertinggal sendiri dan sangat potensial untuk dipasarkan (eksport) ke daerah lain.

iv. Sektor Pertambangan dan Penggalian

Sektor pertambangan dan penggalian ini tingkat kontribusinya tidak terlalu besar terhadap pembentukan PDRB pada rata-rata daerah tertinggal. Hal ini ditunjukkan dengan rata-rata kontribusi sektor ini yang hanya mencapai 6,46 persen sedikit melebihi rata-rata kontribusi sektor yang sama ditingkat Provinsi Kalbar dengan 4,51 persen dan merupakan kontributor tertinggi kelima terhadap pembentukan PDRB pada rata-rata daerah tertinggal. Daerah tertinggal dengan tingkat kontribusi terbesar pada pembentukan PDRB dari sektor pertambangan dan penggalian ini adalah Kabupaten 
Ketapang dengan rata-rata 13,41 persen, sedangkan Kabupaten Sambas merupakan kontributor terkecil untuk sektor ini diantara daerah tertinggal yang lain dengan 0,98 persen. seperti yang ditunjukkan pada gambar 6, persentase kontribusi sektor pertambangan dan penggalian pada rata-rata daerah tertinggal selama lima tahun terakhir terus mengalami penurunan dari 6,98 persen pada tahun 2011 menjadi 5,98 persen pada tahun 2015.

Demikian juga dengan laju pertumbuhan sektor ini yang terus mengalami penurunan selama lima tahun terakhir dengan rata-rata pertumbuhan sektor sebesar 1,08 persen namun masih dibawah laju pertumbuhan sektor yang sama PDRB Provinsi Kalbar dengan rata-rata 1,19 persen, sehingga sektor ini diklasifikasikan sebagai sektor yang maju dan namun pertumbuhannya masih tertekan (potensial). Adapun daerah tertinggal dengan rata-rata tingkat pertumbuhan tertinggi untuk sektor ini adalah Kabupaten Sambas dengan 11,67 persen dan Kabupaten Ketapang merupakan daerah dengan ratarata tingkat pertumbuhan terendah yaitu negatif 3,01 persen.

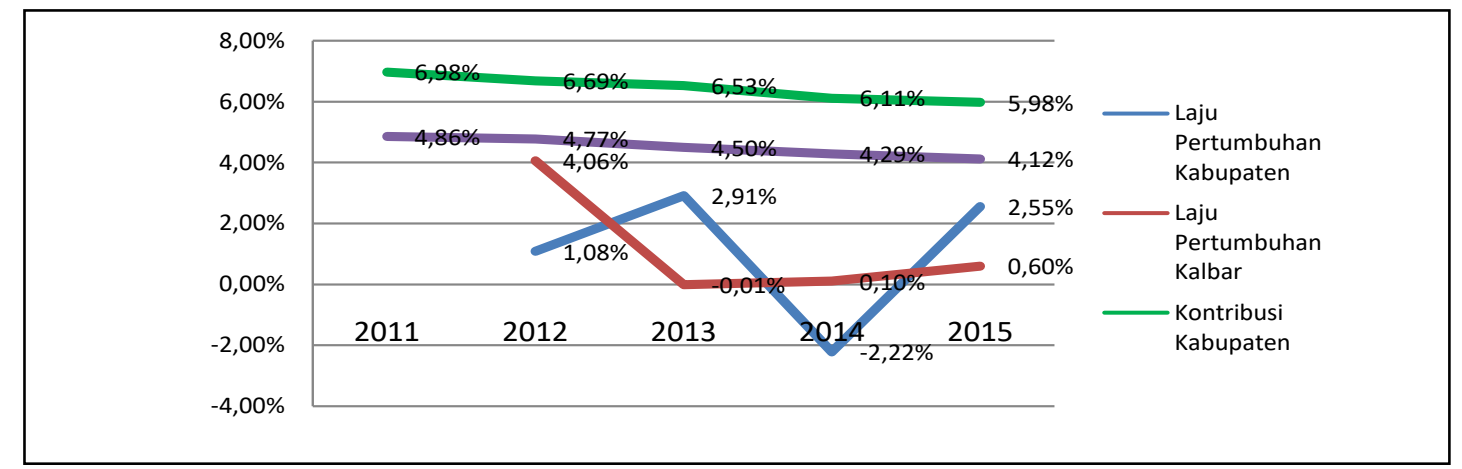

\section{Gambar 6. Grafik Laju Pertumbuhan dan Kontribusi Sektor Pertambangan dan Penggalian Rata-Rata Daerah Tertinggal dan Provinsi Kalbar}

Sektor pertambangan dan penggalian ini juga merupakan sektor penyumbang terjadinya peningkatan kinerja perekonomian pada rata-rata daerah tertinggal dengan pertambahan nilai absolut yang sebesar Rp.4,20 miliar. Namun sektor ini memiliki daya saing (kompetitif) yang lebih rendah dari sektor yang sama pada PDRB Kalbar selama kurun waktu lima tahun terakhir yang ditunjukkan dengan nilai pergeseran diferensial (differential shift) negatif sebesar Rp.417 juta. Sedangkan dengan hasil perhitungan analisis LQ untuk sektor pertambangan dan penggalian ini sebesar rata-rata 1,43 yang berarti bahwa sektor ini merupakan sektor basis yang sudah mampu memenuhi kebutuhan masyarakat pada rata-rata daerah tertinggal sendiri dan sangat potensial untuk dipasarkan (eksport) ke daerah lain.

\subsection{Perubahan Struktur Ekonomi Daerah Tertinggal}

Pertumbuhan ekonomi telah mengakibatkan perubahan struktur perekonomian. Transformasi struktural merupakan proses perubahan struktural perekonomian dari sektor tradisional (pertanian) yaitu sektor primer yang terdiri atas pertanian, kehutanan, 
perikanan dan pertambangan ke sektor sekunder yang terdiri atas industri-industri pengolahan, industri air dan listrik, industri bangunan atau perubahan ke sektor tersier yang terdiri atas bidang pengangkutan dan perhubungan, pemerintahan, perdagangan dan jasa-jasa perseorangan.

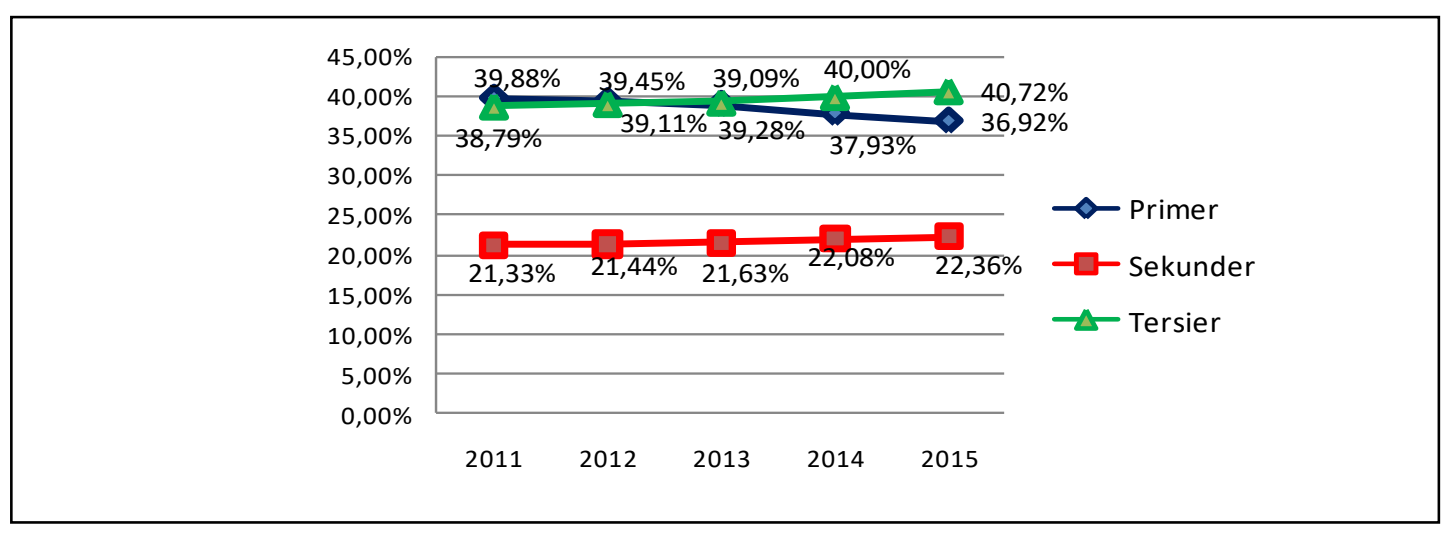

\section{Gambar 7. Grafik Perkembangan Kontribusi Sektor PDRB Rata-Rata Daerah Tertinggal}

Gambar 7 menunjukkan perekonomian rata-rata daerah tertinggal selama tahun 2011 sampai dengan 2015 secara makro didominasi oleh sektor tersier dengan rata-rata 39,58 persen sedikit diatas sektor primer dengan 38,65 persen dan sektor sekunder dengan 21,77 persen. Peranan sektor perekonomian dalam pembentukan PDRB rata-rata daerah tertinggal menunjukkan bahwa sektor primer mengalami penurunan kontribusi dari 39,88 persen pada tahun 2011 menjadi 36,92 persen pada tahun 2015. Peranan sektor sekunder dan sektor tersier pada daerah tertinggal selama periode pengamatan terus mengalami peningkatan kontribusi dari 21,33 persen tahun 2011 menjadi 22,36 persen pada tahun 2015. Demikian juga dengan sektor tersier yang juga terus mengalami kenaikan dari 38,79 persen pada tahun 2011 menjadi 40,72 pada tahun 2015.

Penurunan peranan sektor primer dan meningkatnya peranan sektor sekunder dan tersier pada perekonomian rata-rata daerah tertinggal ini disertai dengan meningkatnya pendapatan perkapita penduduk rata-rata daerah tertinggal dari 17,59 juta pada tahun 2011 menjadi 19,96 juta pada tahun 2015. Peningkatan pendapatan perkapita ini diiringi dengan penurunan laju pertumbuhan penduduk pada rata-rata daerah tertinggal yang semula sebesar 1,84 menjadi tahun 2011 menurun sedikit menjadi 1,70 tahun 2015 .

Adapun kondisi perubahan struktur ekonomi dalam pembentukan masing-masing PDRB daerah tertinggal selama 5 tahun pembangunan yang diikuti dengan tingkat pendapatan perkapita dan laju pertumbuhan penduduk dapat dilihat pada Tabel 5.

Tabel 5 menunjukkan terjadinya penurunan peranan sektor primer dan meningkatnya peranan sektor sekunder dan tersier tahun 2011 sampai dengan 2015 pada hampir seluruh daerah tertinggal di Kalbar. Kabupaten Ketapang menjadi daerah tertinggi penurunan peranan sektor primer dalam perekonomian daerah dengan penurunan sebesar 5,53 persen, sedangkan Bengkayang dan Melawi sebaliknya mengalami peningkatan peranan sektor primer dalam perekonomian daerahnya. 
Perubahan struktur perekonomian dengan terjadinya peningkatan peranan sektor sekunder dan tersier terjadi pada seluruh daerah tertinggal dengan Kab. Sintang dengan peningkatan kontribusi sektor sekunder tertinggi sebesar 1,51 persen sedangkan peningkatan peranan sektor tersier tertinggi terjadi di Kabupaten Kapuas Hulu dengan sebesar 10,39 persen.

Tabel 5. Perubahan Kontribusi Sektor Primer, Sektor Sekunder, Pendapatan Perkapita dan Laju Pertumbuhan Penduduk Daerah tertinggal tahun 2011 dan 2015

\begin{tabular}{|c|c|c|c|c|c|c|c|c|c|c|c|c|c|c|c|}
\hline \multirow{2}{*}{$\begin{array}{l}\text { Kabu- } \\
\text { paten }\end{array}$} & \multicolumn{3}{|c|}{$\begin{array}{c}\text { Kontribusi Sektor } \\
\text { Primer }(\%)\end{array}$} & \multicolumn{3}{|c|}{$\begin{array}{c}\text { Kontribusi Sektor } \\
\text { Sekunder }(\%)\end{array}$} & \multicolumn{3}{|c|}{$\begin{array}{c}\text { Kontribusi Sektor } \\
\text { Tersier }(\%)\end{array}$} & \multicolumn{3}{|c|}{$\begin{array}{l}\text { Perdapatan Perkapita } \\
\text { (dalam juta Rupiah) }\end{array}$} & \multicolumn{3}{|c|}{$\begin{array}{l}\text { Laju Pertumbuhan } \\
\text { Penduduk }(\%)\end{array}$} \\
\hline & 2011 & 2015 & $\Delta$ & 2011 & 2015 & $\Delta$ & 2011 & 2015 & $\Delta$ & 2011 & 2015 & $\Delta$ & 2011 & 2015 & $\Delta$ \\
\hline $\begin{array}{l}\text { Sam- } \\
\text { bas }\end{array}$ & 36,92 & 35,30 & $-1,62$ & 19,55 & 20,40 & 0,85 & 43,53 & 43,79 & 0,26 & 17,07 & 20,48 & 3,41 & 1,01 & 0,62 & $-0,39$ \\
\hline $\begin{array}{l}\text { Beng- } \\
\text { kayang }\end{array}$ & 38,68 & 38,80 & 0,12 & 19,61 & 20,15 & 0,54 & 41,70 & 43,05 & 1,35 & 17,07 & 20,48 & 3,41 & 2,23 & 2,46 & 0,23 \\
\hline Landak & 40,85 & 39,12 & $-1,73$ & 20,70 & 21,18 & 0,48 & 38,45 & 39,70 & 1,25 & 14,04 & 16,11 & 2,07 & 1,76 & 1,33 & $-0,43$ \\
\hline $\begin{array}{l}\text { Keta- } \\
\text { pang }\end{array}$ & 47,81 & 42,28 & $-5,53$ & 22,56 & 23,91 & 1,35 & 29,63 & 33,81 & 4,18 & 26,01 & 28,42 & 2,41 & 2,38 & 2,53 & 0,15 \\
\hline $\begin{array}{l}\text { Sin- } \\
\text { tang }\end{array}$ & 36,89 & 33,97 & $-2,92$ & 19,85 & 21,36 & 1,51 & 43,26 & 44,67 & 1,41 & 17,02 & 19,76 & 2,74 & 1,80 & 1,43 & $-0,37$ \\
\hline $\begin{array}{l}\text { Kapuas } \\
\text { Hulu }\end{array}$ & 34,63 & 32,82 & $-1,81$ & 29,02 & 30,44 & 1,42 & 36,35 & 46,74 & 10,39 & 19,46 & 21,55 & 2,09 & 2,21 & 2,32 & 0,11 \\
\hline Melawi & 32,04 & 39,89 & 7,85 & 16,39 & 17,70 & 1,31 & 51,57 & 52,41 & 0,84 & 12,62 & 14,32 & 1,70 & 2,00 & 1,92 & $-0,08$ \\
\hline $\begin{array}{l}\text { Kayong } \\
\text { Utara }\end{array}$ & 37,70 & 36,09 & $-1,61$ & 20,35 & 20,46 & 0,11 & 41,94 & 43,44 & 1,50 & 17,09 & 19,01 & 1,92 & 2,14 & 2,13 & $-0,01$ \\
\hline
\end{tabular}

Seiring dengan terjadinya penurunan peranan sektor primer dan meningkatnya peranan sektor sekunder dan tersier, tabel 5 menunjukkan bahwa peningkatan pendapatan perkapita penduduk tahun 2011 dan tahun 2015 terjadi pada seluruh daerah tertinggal dengan tertinggi pendapatan perkapita penduduk adalah Kabupaten Sambas dan Bengkayang. Perubahan struktur perekonomian pada sebagian besar daerah tertinggal yang diiringi dengan meningkatnya pendapatan perkapita penduduk pada seluruh daerah tertinggal, juga diiringi dengan penurunan laju pertumbuhan penduduk yang terjadi pada lima daerah tertinggal dengan penurunan laju pertumbuhan penduduk tertinggi terjadi di Kabupaten Landak dengan 0,43 persen dari tahun 2011 s.d. 2015.

Perubahan strukur perekonomian pada daerah tertinggal dapat juga dilihat dari peranan sektor utama dalam penyerapan tenaga kerja. Peranan sektor primer dalam 
menyediakan kesempatan kerja pada rata-rata daerah tertinggal mengalami penurunan dari tahun 2011 sebesar 71,79 persen menjadi 69,66 pada tahun 2015. Penurunan penyerapan tenaga kerja sektor primer ini terlihat pada gambar 8 terjadi pada Kabupaten Sambas sebesar menurun 10,05 persen, Sintang menurun sebesar 2,46 persen, Kapuas Hulu menurun sebesar 5,81 persen dan melawi menurun sebesar 8,46. Sedangkan Kabupaten Bengkayang mengalami peningkatan penyerapan tenaga kerja pada sektor primer ini sebesar 4,05 persen, Landak meningkat sebesar 0,72 persen, Ketapang meningkat sebesar 4,29 persen dan Kayong Utara meningkat sebesar 0,68 persen. Namun, secara umum penyerapan tenaga kerja untuk sektor primer pada rata-rata daerah tertinggal mengalami penurunan sebesar 2,13 persen.

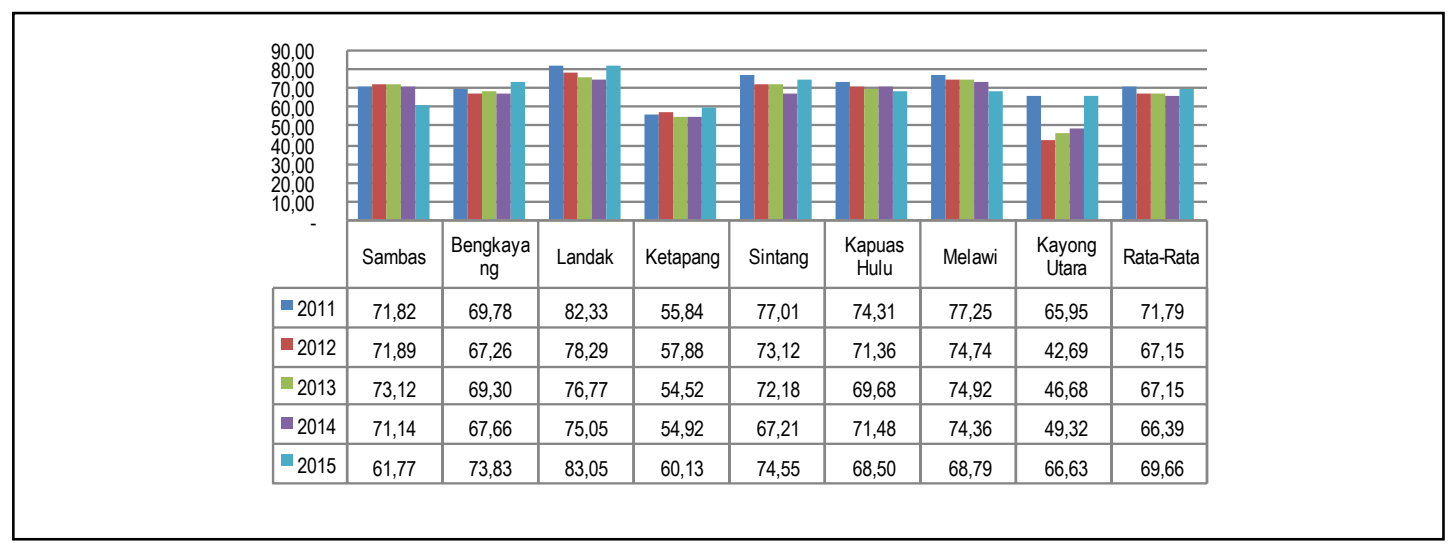

Gambar 8. Penyerapan Tenaga Kerja Sektor Primer Daerah Tertinggal Tahun 2011-2015

Peranan sektor sekunder dalam penyerapan tenaga kerja pada rata-rata daerah tertinggal juga mengalami penurunan dari tahun 2011 sebesar 10,06 persen menjadi 8,88 pada tahun 2015. Penurunan penyerapan tenaga kerja sektor sekunder ini terjadi pada hampir seluruh daerah tertinggal terlihat pada gambar 9 yaitu Kabupaten Bengkayang menurun sebesar 2,7 persen, Landak menurun sebesar 0,21 persen, Ketapang menurun sebesar 5,18 persen, Sintang menurun 1,90 persen, Melawi menurusn sebesar 1,14 persen dan Kayong Utara sebesar 3,13 persen.

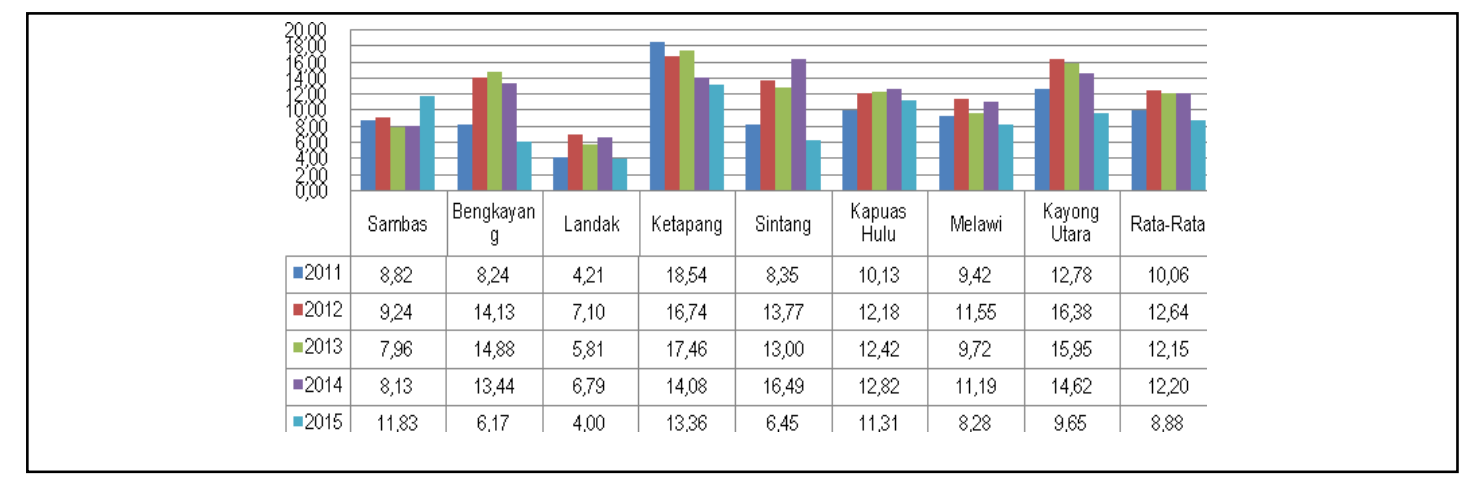

Gambar 9. Penyerapan Tenaga Kerja Sektor Sekunder Daerah Tertinggal

Tahun 2011-2015 
Sedangkan Kabupaten Sambas dan Kapuas Hulu mengalami peningkatan penyerapan tenaga kerja pada sektor sekunder ini masing-masing sebesar 3,01 persen dan 1,18 persen. Dengan demikian secara umum penyerapan tenaga kerja untuk sektor sekunder pada rata-rata daerah tertinggal mengalami penurunan sebesar 1,18 persen.

Penurunan peranan sektor primer dan sekunder terhadap penyediaan kesempatan kerja pada daerah tertinggal tidak diikuti dengan peranan pada sektor tersier. Peranan sektor tersier dalam penyerapan tenaga kerja pada rata-rata daerah tertinggal mengalami peningkatan dari tahun 2011 sebesar 18,15 persen menjadi 21,46 persen pada tahun 2015. Peningkatan penyerapan tenaga kerja pada sektor tersier ini terjadi pada hampir seluruh daerah tertinggal di Kalbar terlihat pada gambar 10 yaitu Kabupaten Sambas meningkat sebesar 7,04 persen, Ketapang meningkat sebesar 0,89 persen, Sintang meningkat 4,39 persen, Kapuas Hulu meningkat 4,63 persen, Melawi meningkat 9,60 persen dan Kayong Utara meningkat sebesar 2,45 persen. Sementara itu Kabupaten Bengkayang dan Landak mengalami penurunan penyerapan tenaga kerja pada sektor tersier ini masing-masing sebesar 1,98 persen dan 0,51 persen. Dengan demikian secara umum penyerapan tenaga kerja untuk sektor tersier pada rata-rata daerah tertinggal mengalami peningkatan sebesar rata-rata 3,31 persen.

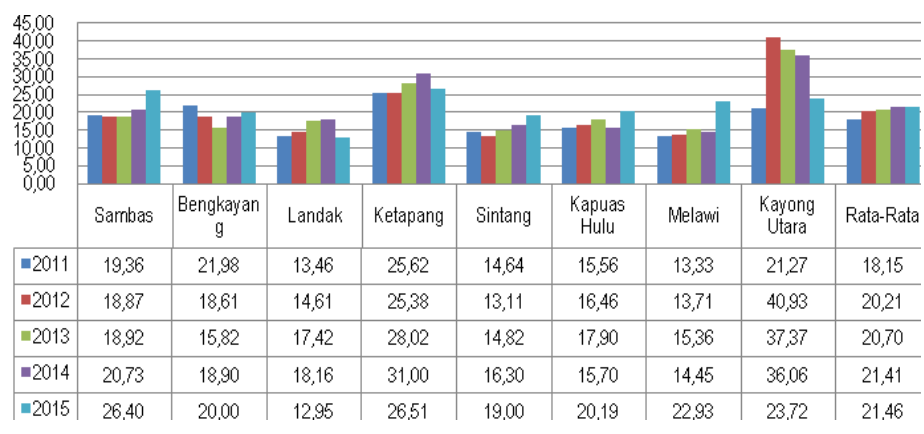

Gambar 10. Penyerapan Tenaga Kerja Sektor Tersier Daerah Tertinggal Tahun 2011-2015

Peranan sektor primer dalam pembentukan PDRB daerah tertinggal selama lima tahun terakhir relatif sedikit menurun disertai dengan menurunnya penyerapan tenaga kerja di sektor ini, sedangkan pendapatan perkapita terus mengalami peningkatan sementara laju pertumbuhan penduduk rata-rata daerah tertinggal terus sedikit mengalami penurunan. Peranan sektor sekunder dalam pembentukan PDRB daerah tertinggal selama lima tahun terakhir relatif sedikit meningkat, namun tidak disertai dengan meningkatnya penyerapan tenaga pada sektor ini yang cenderung sedikit menurun. Sedangkan peranan sektor tersier dalam pembentukan PDRB daerah tertinggal selama lima tahun terakhir relatif terus mengalami peningkatan seperti halnya sektor sekunder yang disertai dengan meningkatnya penyerapan tenaga kerja pada sektor ini. Dengan demikian dapat disimpulkan bahwa telah terjadi perubahan struktural ekonomi pada daerah-daerah tertinggal dari sektor primer ke sektor tersier dan sektor sekunder. 
Pergesaran peranan sektor terhadap pembentukan PDRB daerah tertinggal ini sesuai dengan pemikiran ekonom dunia Clark - Fisher (1951) dalam Adisasmita (2005) mengenai transformasi struktural adalah pergeseran tenaga kerja dan investasi dari sektor primer ke sektor sekunder dan kemudian ke sektor tersier, makin tinggi pendapatan per kapita suatu negara makin kecil peranan sektor pertanian dalam menyediakan kesempatan kerja. Namun sebaliknya, sektor industri makin penting peranannya dalam menampung tenaga kerja. Fisher (1951) dalam Adisasmita (2005) mengemukakan bahwa pertumbuhan ekonomi disertai dengan pergeseran permintaan dari sektor primer ke sektor sekunder dan akhirnya ke sektor tersier yang mengakibatkan perubahan dalam struktur produksi melalui pergeseran kesempatan kerja dan alokasi dana. Hal ini juga sejalan demikian pemikiran Chenery \& Syrquin (1975) dalam Tambunan (2001) bahwa sejalan bahwa sejalan dengan peningkatan pendapatan masyarakat per kapita yang membawa perubahan dalam pola permintaan konsumen dari penekanan pada makanan dan barang-barang kebutuhan pokok lain ke berbagai macam barang-barang manufaktur dan jasa, akumulasi kapital fisik dan manusia (SDM), perkembangan kota-kota dan industri-industri di urban bersamaan dengan proses migrasi penduduk dari pedesaan ke perkotaan, dan penurunan laju pertumbuhan penduduk dan family size yang semakin kecil, struktur perekonomian suatu negara bergeser dari yang semula didominasi oleh sektor pertanian atau dan sektor pertambangan menuju ke sektor-sektor non primer, khususnya industri.

Perubahan struktural ekonomi pada daerah tertinggal ini sejalan dengan penelitian yang dilakukan oleh Ramda \& Utama (2017) yang melakukan analisis terhadap pergeseran struktur ekonomi dan potensi sektor ekonomi Kabupaten Manggarai Periode 2010-2015 yang menyimpulkan bahwa Kabupaten Manggarai mengalami pergeseran struktur ekonomi yang diakibatkan oleh perubahan kontribusi sektor perekonomian pada sektor primer menuju sektor tersier berdasarkan analisis shift share.

Hasil penelitian ini juga sejalan dengan penelitian yang dilakukan Sawhney (2010) yang melakukan analisis terhadap pertumbuhan dan perubahan struktur perekonomian di negara-negara South Asian Association Regional Cooperation (SAARC) yang terdiri dari tujuh negara anggota, yaitu, Bangladesh, Bhutan, India, Maladewa, Nepal, Pakistan dan SriLanka selama dua dekade yaitu dari 1988 hingga 2008 dimana hasil penelitian menyimpulkan bawa pola trasformasi struktural ekonomi negara-negara SAARC tidak sama atau menyimpang dari pola klasik proses transformasi struktural ekonomi di negara-negara maju yang dijelaskan para ekonom dunia seperti Kuznets (1966, 1971), Fisher (1935, 1939) dan Chenery (1979), yang mengemukakan bahwa proses transformasi struktural bergeser dari sektor primer ke sektor sekunder dan kemudian ke sektor tersier. Namun dari hasil penelitian Sawhney (2010) menunjukkan bahwa sebagian besar negara-negara seperti India sebelum mencapai tingkat pertumbuhan ekonomi yang didorong oleh sektor jasa, sektor ekonomi industrinya belum bertumbuh secara maksimal dengan sektor jasa merupakan sektor tertinggi pembentukan PDB negara-negara SAARC dan merupakan persentase tertinggi di sektor tersier. 
Pergeseran peranan sektor primer dalam perekonomian pada suatu daerah menurut teori Lewis (1960) dalam Tambunan (2001) terjadi karena di perdesaan, tingkat pertumbuhan penduduknya tinggi sehingga terjadi kelebihan supply tenaga kerja yang membuat tingkat upah menjadi rendah. Sebaliknya diperkotaan, sektor industri mengalami kekurangan tenaga kerja yang membuat banyak menarik tenaga kerja dari sektor pedesaan ke sektor perkotaan sehingga terjadi proses urbanisasi dan migrasi. Perhatian utama dari model ini diarahkan pada terjadinya proses pengalihan tenaga kerja, serta pertumbuhan output dan peningkatan penyerapan tenaga kerja disektor modern.

Perubahan struktural atau pergeseran sektor ekonomi yang terjadi pada daerah tertinggal di Kalbar merupakan sebuah dinamika pertumbuhan ekonomi daerah. Menurut Adisasmita (2005), sebagian besar penduduk suatu daerah awalnya bekerja dan menggantungkan diri pada sektor pertanian yang ditunjukkan dengan besarnya persentase kontribusi dan jumlah tenaga kerja pada sektor ini. Dengan kemajuan transportasi akan mendorong terjadinya perdagangan antar daerah. Perkembangan perdagangan antar daerah ini tentunya akan memacu prioritas pengembangan hasil-hasil sektor pertanian tanaman pangan, yang selanjutnya diikuti oleh sub sektor peternakan dan perikanan. Pengembangan hasil-hasil sektor pertanian ini selanjutnya memunculkan perkembangan pada berbagai sektor industri sekunder yang melakukan pengolahan berbagai produk dari sektor primer yang diperluas semakin berspesialisasi dan kemudian tentunya akan meningkatkan pengembangan sektor jasa yang akan melayani berbagai permintaan baik dari dalam maupun dari luar daerah.

Perubahan struktural ekonomi daerah tertinggal di Kalbar dapat disimpulkan sedikit menyimpang dari pola perubahan struktural di negara-negara maju. Namun perubahan struktual ini cenderung sama dengan perubahan struktural yang terjadi pada sebagian besar negara-negara sedang berkembang yaitu pergeseran peranan sektor dari primer ke tersier dan kemudian ke sektor sekunder. Hal ini disebabkan karena pertumbuhan industrialisasi di daerah tertinggal cenderung melambat karena daerah tertinggal di Kalbar lebih terfokus pada pemanfaatan sumber daya alam dengan tidak memaksimalkan peran sektor industri untuk melakukan pengolahan/pemanfaatan lebih atas hasil dari sektor primer seperti pertanian, kehutanan dan perikanan yang jika diolah dengan cara modern akan menghasilkan nilai lebih terhadap perekonomian daerah tertinggal.

Transformasi struktural perekonomian pada daerah tertinggal telah memunculkan kondisi dimana sektor tersier merupakan sektor dengan peranan terbesar terhadap pembentukan PDRB pada seluruh daerah tertinggal dan terjadi peningkatan penyerapan tenaga kerja selama lima tahun terakhir pada sektor ini. Sektor perdagangan besar dan eceran, reparasi mobil dan sepeda motor merupakan sektor dengan kontribusi terbesar untuk sektor tersier ini dengan rata-rata kontribusi pada daerah tertinggal sebesar 14,85 persen dan merupakan kontributor terbesar kedua pembentukan PDRB daerah tertinggal setelah sektor pertanian. Sektor ini selama lima tahun terakhir mengalami pertumbuhan 
yang cukup stabil dan sedikit meningkat dari 4,41 persen pada tahun 2012 menjadi 6,74 pada tahun 2015 .

Kondisi perubahan struktural perekonomian daerah tertinggal kedepannya akan semakin meningkatkan pangsa relatif sektor industri dan jasa serta dikhawatirkan semakin menurunkan pangsa relatif sektor pertanian yang memang masih memegang peranan yang dominan dalam perekonomian daerah tertinggal. Transformasi struktur ketenagakerjaan daerah tertinggal harus sejalan dengan transformasi struktur perekonomiannya, jika tidak maka yang terjadi adalah ketimpangan pendapatan yang semakin tajam antara tenaga kerja pada sektor pertanian dengan sektor lainnya di daerah tertinggal. Sektor primer pada daerah tertinggal akan menanggung beban yang sangat berat karena di sektor pertanian akan terjadi penumpukan tenaga kerja dan pada sisi lain harus menopang kehidupan sektor-sektor lainnya.

Penumpukan tenaga kerja di perdesaan pada daerah tertinggal di Kalbar terlihat jelas pada persentase penduduk usia kerja pada tahun 2015 dimana rata-rata sebanyak 86,6 persen penduduk usia kerja berada di desa dan sebanyak 13,4 persen berada di perkotaan. Hal ini diperparah lagi dengan kualitas pekerja pada daerah tertinggal yang terlihat dari persentase penduduk bekerja tahun 2015 menurut tingkat pendidikan dimana rata-rata sebanyak 59,34 persen pekerja di daerah tertinggal berpendidikan SD, sebanyak 17,16 persen berpendidikan SMP dan sebanyak 23,49 pekerja di daerah tertinggal berpendidikan SLTA ke atas. Dengan persentase tenaga kerja pada daerah tertinggal yang lebih terkonsentrasi di perdesaan dengan tingkat pendidikan yang rata-rata lebih rendah dari perkotaan, pendapatan yang diperoleh dari sektor tradisional tidak hanya lebih rendah tetapi juga lebih timpang apabila dibandingkan dengan pendapatan di sektor sekunder dan tersier yang dihasilkan oleh pekerja di perkotaan.

Pemerintah daerah tertinggal selain memaksimalkan pengembangan sektor unggulan namun juga harus mempertimbangkan sektor lain yang memilki tingkat kontribusi yang besar terhadap penyerapan tenaga kerja maupun perekonomian daerah. Sektor pertanian, kehutanan dan perikanan perlu mendapat perhatian khusus karena merupakan sektor basis dengan tingkat penyerapan tenaga kerja terbesar di daerah tertinggal dengan jumlah tenaga kerja terserap sektor pertanian sebanyak kurang lebih 852 ribu pekerja atau sebesar 69 persen dari total seluruh tenaga kerja pada seluruh daerah tertinggal. Namun produktivitas pekerja pada sektor pertanian ini sangat rendah dimana dengan pekerja sebanyak 69,66 persen dari total tenaga kerja pada seluruh daerah tertinggal pada tahun 2015 hanya menghasilkan kontribusi PDRB sebesar rata-rata 38,65 persen. Hal ini berbanding terbalik dengan produktivitas pekerja pada sektor sekunder dan tersier. Sektor sekunder dengan penyerapan tenaga kerja sebanyak 8,8 persen dapat berkontribusi sebesar 21,77 persen pembentukan PDRB rata-rata daerah tertinggal. Demikian pula dengan sektor tersier dengan tenaga kerja sebanyak 21,46 berkontribusi terhadap pembentukan PDRB rata-rata daerah tertinggal sebesar 39,58 persen. 
Program pembangunan ekonomi di daerah tertinggal hendaknya mengutamakan pengembangan dan mempertahankan pertumbuhan serta meningkatkan produktivitas sektor unggulan daerah. Pemerintah daerah tertinggal juga hendaknya memprioritaskan pengembangan sektor-sektor ekonomi yang masuk dalam kategori potensial untuk kedepannya diupayakan menjadi sektor yang maju dan tumbuh pesat dengan memperbesar porsi outputnya. Dengan demikian, kegiatan investasi merupakan sebuah solusi yang perlu ditingkatkan untuk memanfaatkan berbagai potensi daerah, meliputi berbagai sumber daya alam dengan kandungan mineral logam, sumber daya hutan dan perairan, pengembangan pertanian dan agribisnis, serta potensi pariwisata yang dapat dimanfaatkan untuk meningkatkan perekonomian dan kesejahteraan masyarakat daerah tertinggal.

Selain itu pemerintah daerah tertinggal perlu mengoptimalkan berbagai potensi sektor ekonomi daerah melalui diversifikasi vertikal maupun diversifikasi horizontal. Diversifikasi vertikal artinya daerah berupaya memberikan nilai tambah pada Sumber Daya Alam dengan cara mengolah menjadi barang setengah jadi maupun barang jadi. Sementara itu diversifikasi horizontal mengandung makna daerah memperbanyak ragam sektor usaha yang digarap, tidak hanya bergantung pada satu sektor tertentu.

Mengingat pentingnya investasi bagi pertumbuhan ekonomi daerah, hal yang perlu diperhatikan oleh pemerintah daerah tertinggal adalah kelembagaan yang ramah dunia usaha. Pencapaian nilai tambah pada komponen investasi diantaranya dipengaruhi oleh pembenahan sarana infrastruktur, penyediaan jaringan listrik dan air bersih, pengurusan perizinan usaha, kepastian hukum dan kondisi keamanan suatu daerah. Pembangunan infrastruktur yang baik akan menjamin efisiensi, memperlancar pergerakan barang dan jasa, dan meningkatkan nilai tambah perekonomian serta menjamin keberlangsungan investasi. Ketersediaan infrastruktur juga akan menjadi salah satu faktor pendorong produktivitas pekerja, keberadaan infratsruktur seperti jalan raya, pelabuhan dan jembatan akan mampu membuka dan mempermudah akses bagi masyarakat dalam melaksanakan aktivitas ekonomi yang pada akhirnya akan berdampak pada meningkatnya pendapatan dan kesejahteraan masyarakat.

\section{4) SIMPULAN}

Sektor pertanian, kehutanan dan perikanan merupakan sektor perekonomian dengan rata-rata tingkat kontribusi terbesar pada seluruh daerah tertinggal di Provinsi Kalimantan Barat. Kontribusi sektor pertanian, kehutanan dan perikanan terbesar di Kabupaten Landak dan terendah di Kabupaten Melawi. Sedangkan sektor pengadaan listrik dan gas merupakan sektor perekonomian dengan rata-rata kontribusi terkecil pada pembentukan PDRB seluruh daerah tertinggal dengan kontribusi terkecil di Kabupaten Bengkayang, Kabupaten Landak dan Kabupaten Kapuas Hulu.

Sektor real estate dan sektor jasa kesehatan dan sosial merupakan sektor unggulan pada sebagian besar daerah tertinggal meliputi Kabupaten Sambas, Kabupaten 
Bengkayang, Kabupaten Landak, Kabupaten Melawi dan Kabupaten Kayong Utara. Sedangkan sektor pertanian, kehutanan dan perikanan serta sektor pertambangan dan penggalian merupakan sektor potensial menjadi sektor unggulan pada sebagian besar daerah tertinggal di Provinsi Kalimantan Barat.

Telah terjadi transformasi struktural perekonomian pada seluruh daerah tertinggal di Provinsi Kalimantan Barat yaitu dari sektor primer ke sektor tersier dan sekunder yang ditandai dengan menurunnya peranan sektor primer dan meningkatnya peranan sektor tersier dan sekunder terhadap pembentukan PDRB dan penyerapan tenaga kerja.

Untuk memacu pertumbuhan ekonomi daerah tertinggal di Provinsi Kalimantan Barat hendaknya memprioritaskan pembangunan dengan merumuskan program dan kebijakan ekonomi yang mengutamakan pengembangan, mempertahankan pertumbuhan dan meningkatkan produktivitas sektor ekonomi yang menjadi unggulan daerah. Selain itu program dan kebijakan pembangunan ekonomi pada daerah tertinggal hendaknya juga mempertimbangkan transformasi struktural ekonomi yang terjadi serta mengarahkan perhatian pada sektor-sektor potensial yang berkontribusi dominan terhadap pembentukan PDRB dan penyerapan tenaga kerja.

Penelitian ini masih terbatas pada tahapan penentuan komoditi unggulan dan program pengembangan per sektor yang lebih seusai dengan karakteristik daerah, kepada peneliti lainnya disarankan agar melanjutkan penelitian sampai tahap penentuan komoditi unggulan dan program pengembangan komoditi unggulan dengan periode penelitian yang lebih panjang (10 tahun) dikarenakan memungkinkan untuk mendapat hasil analisis pertumbuhan, pergeseran sektor dan perubahan struktur ekonomi yang lebih stabil

\section{DAFTAR PUSTAKA}

Adisasmita, R. (2005). Dasar-Dasar Ekonomi Wilayah. Yogyakarta: Graha Ilmu.

Ambardi, U.M., \& Socia, P. (2002). Pengembangan Wilayah dan Otonomi Daerah. Jakarta: Pusat Pengkajian Kebijakan Teknologi Pengembangan Wilayah (P2KTPW-BPPT).

Arsyad, L. (2002). Pengantar Perencanaan Pembangunan Ekonomi Daerah. Yogyakarta: BPFE.

Badan Pusat Statistik. (2012). Statistik Ketenagakerjaan Provinsi Kalimantan Barat Tahun 2011. Pontianak: BPS.

Badan Pusat Statistik. (2013). Statistik Ketenagakerjaan Provinsi Kalimantan Barat Tahun 2012. Pontianak: BPS.

Badan Pusat Statistik. (2014). Statistik Ketenagakerjaan Provinsi Kalimantan Barat Tahun 2013. Pontianak: BPS. 
Badan Pusat Statistik. (2015). Statistik Ketenagakerjaan Provinsi Kalimantan Barat Tahun 2014. Pontianak: BPS.

Badan Pusat Statistik. (2016). Statistik Ketenagakerjaan Provinsi Kalimantan Barat Tahun 2015. Pontianak: BPS.

Badan Pusat Statistik. (2016). Kabupaten Bengkayang dalam Angka 2016. Bengkayang: BPS.

Badan Pusat Statistik. (2016). Kabupaten Kapuas Hulu dalam Angka 2016. Kapuas Hulu: BPS.

Badan Pusat Statistik. (2016). Kabupaten Kayong Utara dalam Angka 2016. Kayong Utara: BPS.

Badan Pusat Statistik. (2016). Kabupaten Ketapang dalam Angka 2016. Ketapang: BPS.

Badan Pusat Statistik. (2016). Kabupaten Landak dalam Angka 2016. Landak: BPS.

Badan Pusat Statistik. (2016). Kabupaten Melawi dalam Angka 2016. Melawi: BPS.

Badan Pusat Statistik. (2016). Kabupaten Sambas dalam Angka 2016. Sambas: BPS.

Badan Pusat Statistik. (2016). Kabupaten Sintang dalam Angka 2016. Sintang: BPS.

Badan Pusat Statistik. (2016). Produk Domestik Regional Bruto Provinsi Kalimantan Barat Menurut Lapangan Usaha 2011-2015. Pontianak: BPS.

Jhingan, M. L. (2014). Ekonomi Pembangunan dan Perencanaan. Jakarta: Rajawali Pers.

Kuncoro, M. (2010). Dasar-dasar Ekonomika Pembangunan. Yogyakarta: UPP STIM YKPN.

Kuncoro, M. (2012). Perencanaan Daerah "Bagaimana Membangun Ekonomi Lokal, Kota dan Kawasan”. Jakarta: Salemba Empat.

Mardiana, I.W., Budhi, M.K.S., \& Swara, I. W. Y. (2017). Analisis Pergeseran Struktur Ekonomi dan Sektor Unggulan di Kabupaten Tabanan Provinsi Bali. Jurnal Ekonomi Pembangunan Universitas Udayana, 6 (3), 414-444, ISSN: 2303-0178.

Mardiasmo. (2004). Otonomi dan Manajemen Keuangan Daerah. Yogyakarta: ANDI OFFSET.

Oktavilia, S. (2011). Pengembangan Potensi Ekonomi Lokal Daerah Tertinggal sebagai Upaya untuk Mengatasi Disparitas Pendapatan Antar Daerah di Provinsi Jawa Tengah. Prosiding SNaPP2011 Sosial, Ekonomi dan Humaniora, ISSN: 20893590.

Ramda, E. E., \& Utama, M. S. (2017). Pergeseran Struktur Ekonomi dan Potensi Sektor Ekonomi Kabupaten Manggarai Periode 2010-2015. E-Jurnal Ekonomi Pembangunan Universitas Udayana, 6 (3), 312-336, ISSN: 2303-0178. 
Sawhney, U. (2010). Growth and Structural Change In SAARC Economies. International Journal Of Economics and Finance Studies, 2 (2), 95-103, ISSN: 1309-8055.

Sjafrizal. (2008). Ekonomi Regional Teori dan Aplikasi. Padang: Baduose Media.

Suratman, E., \& Wahyudi. (2009). Teknik Analisis Perencanaan Pembangunan. Pontianak: Badan Penerbit Universitas Tanjungpura.

Tambunan, T. T. H. (2001). Transformasi Ekonomi di Indonesia. Jakarta: Salemba Empat.

Tarigan, R. (2014). Ekonomi Regional, Teori dan Aplikasi (Edisi Revisi). Jakarta: PT. Bumi Aksara.

Todaro, M. P., \& Smith, S. C. (2011). Pembangunan Ekonomi. Jakarta: Erlangga.

Widodo, T. (2006). Perencanaan Pembangunan Aplikasi Komputer (Era Otonomi Daerah). Yogyakarta: UPP STIM YKPN 